\title{
Why Did So Many Poor-Performing Firms Come to Market in the Late 1990s?: Nasdaq Listing Standards and the Bubble
}

\author{
April Klein \\ Stern School of Business \\ New York University \\ $44 \mathrm{~W} 4^{\text {th }}$ St, Suite $10-92$ \\ New York, NY 10012 \\ aklein@stern.nyu.edu \\ Partha S. Mohanram \\ Columbia Business School \\ 605-A Uris Hall, \\ 3022 Broadway \\ New York, NY 10027 \\ pm2128@columbia.edu
}

\begin{abstract}
We thank Eugene Fama, Ken French and Jay Ritter for allowing us to use their datasets of new listings and internet IPOs. We also thank Nahum Melumad, Doron Nissim, Roberta Romano, Andy Schmidt, and seminar participants at the Joint Columbia-NYU seminar, NYU Law and Economics seminar, Baruch College, University of Delaware, University of Minnesota and Northwestern University for their comments. We thank Woo-Jin Chang, Ron Shalev and Manu Zur for able research assistance.
\end{abstract}




\title{
Why Did So Many Poor-Performing Firms Come to Market in the Late 1990s?: Nasdaq Listing Standards and the Bubble
}

\begin{abstract}
This paper examines the impact of Nasdaq Listing Standards on the composition of new listings in the late 1990s. The Nasdaq has two types of listing standards: one based on profitability and the second based explicitly or implicitly on market capitalization. Specifically, unprofitable firms are allowed to list if either their pro-forma net tangible assets, which include the anticipated proceeds from their IPO, exceeds $\$ 18$ million or their market capitalization exceeds $\$ 75$ million. We show that as the market bubble accelerated in the late 1990s, a vast majority of firms entered under a market capitalization based standard, and these firms became a substantial portion of the Nasdaq. Subsequently, these firms performed the poorest both in terms of financial performance, stock return performance as well as involuntary delistings, while firms that listed under the profitability standard performed much better. In addition, firms that entered under market capitalization standards also exhibited the greatest return volatility. These results illustrate the importance of a profitability standard and the danger of a market capitalization based standard (explicit or implicit) in a market that is in, what ex-post turns out to be, a bubble.
\end{abstract}




\section{Introduction}

Much has been written on the precipitous rise and fall of the Nasdaq in the late 1990s. One particular phenomenon that has been documented is the advent of a seemingly new cadre of new listings on the Nasdaq National Market (NNM) during its boom period. Compared to previous waves of new listings, most firms in the late 1990s came to market with large losses, few revenues, and negative cash flows (Hand, 2000; Schultz and Zaman, 2001; Fama and French, 2001; Ljungqvist and Wilhelm, 2003; Loughran and Ritter, 2004). Upon listing, these firms exhibited extremely high underpricing premiums. Yet, as Ritter and Welch (2002) show, the three-year raw returns for new listings were an unprecedented $-46.2 \%$ and $-64.7 \%$ for stocks that went public in 1999 and 2000 respectively.

One crucial unanswered question is how these firms came to market. In this paper, we demonstrate that the Nasdaq's National Market (NNM) initial listing standards are partially responsible for the influx of poorly-performing IPOs during the Nasdaq market bubble of the late 1990s. Unlike the NYSE, which required minimum pretax earnings for virtually all of its new listings during the market bubble, two of the Nasdaq's listing standards allowed firms to newlylist solely if they were able to raise adequate equity capital. We argue and show that a large number of low-performing firms entered the NNM during the late 1990s under these nonprofitability/market capitalization (implicit or explicit) standards. In fact, we find that under these standards, over $75 \%$ of the firms would not have been able to newly-list except for the fact that they were able to go public and raise the requisite amount of capital to exceed the NNM's required threshold. As we show, these firms displayed negative earnings, operating cash flows, and negative stock returns over time. As a result, many of these firms eventually were delisted 
for involuntary reasons, i.e., they fell below the $\$ 1$ minimum bid price or below the continuing listing standard of a minimum market capitalization. In contrast, we find that newly-listed firms that entered the NNM under an alternative minimum pretax earnings listing standard had positive earnings, operating cash flows, and positive stock returns over time. As we show, many of these firms were able to survive the bursting of the Nadaq bubble in 2000 .

We perform our analyses for firms that newly-listed on the NNM between August 1997 and June 2000. There are several advantages to using this group of new listings during this time period. First, beginning in August 1997, there were three mutually-exclusive alternative sets of quantitative initial listing standards on the NNM. Under alternative 1, newly-listed firms were required to have a minimum pretax income of $\$ 1$ million for the latest fiscal year and $\$ 6$ million in net tangible assets (assets minus liabilities minus goodwill) at the time of listing. Under alternative 2, newly-listed firms were required to have a minimum $\$ 18$ million in net tangible assets at the time of listing. Under alternative 3, a firm was allowed to enter the NNM if it had either $\$ 75$ million in market capitalization or $\$ 75$ in revenues and total assets. Thus, alternative 1 was the only standard that required profitability. Further, since net tangible assets include the net proceeds from the stock offering, alternative 2 is, in effect, an implicit market capitalization standard. Alternative 3 can be interpreted as an explicit market capitalization standard if the firm entered under the minimum $\$ 75$ million market capitalization requirement. Thus, we are able to examine the long-run differences in profitability and risk between firms entering the NNM under a profitability standard vis-à-vis a market capitalization standard. ${ }^{1}$

\footnotetext{
${ }^{1}$ In contrast, the NYSE's initial quantitative standards over this time period required all newly-listed firms to have an aggregate of $\$ 6.5$ million in pretax earnings over their past three years (all years being positive), with the following exceptions. Companies with at least $\$ 500$ million in global market capitalization and $\$ 200$ million in the past year's revenues could alternatively list if they had an aggregate $\$ 25$ in operating cash flows over the past three years. This can be interpreted as an alternative profitability quantitative standard. Beginning June 1999, firms with a market capitalization of at least $\$ 1$ billion and $\$ 250$ million in the past year's revenues could also list without
} 
Second, the use of a single market (the NNM) allows us to isolate these differences without the confounding affects of different market rules and trading venues. Several papers show that different markets provide differing degrees of liquidity, (for example, see Christie and Huang (1994), Christie and Schultz (1994), Bessembinder (1999) or Macey, O’Hara, and Pompilio (2005)), which may influence our returns and volatility of returns analyses. Dharan and Ikenberry (1995) demonstrate an adverse affect of firms moving from the Nasdaq to the NYSE and AMEX, suggesting a trading venue effect that we eliminate. Each market has its own set of quantitative and qualitative initial listing standards, with the Nasdaq having different rules for the NNM, the Small Cap Market and the OTC Bulletin Board. Further, as Macey, O'Hara and Pompilio (2005) show, the Nasdaq and the NYSE have different delisting processes and substantially different rates of firms delisting for involuntary reasons over our time period.

Third, our time period coincides with several events. In August 1997, the Nasdaq changed its initial listing standards by (1) increasing the quantitative levels for alternatives 1 and 2 , (2) reducing the required operating history from three years to two years for alternative 2 , and (3) introducing an explicit market capitalization (alternative 3). Seguin and Smoller (1997) demonstrate that the percentage of penny stocks (with an original listing price under \$3) dropped substantially when the Nasdaq increased its quantitative listing standards in 1981 and 1992, respectively. Thus, by beginning our analysis in August 1997, we examine our new listings under one set of initial listing standards. From August 1997 through June 2000, the Nasdaq Composite Index rose from 1,594 to 3,966, an increase of almost 250\%. Therefore, our sample of new listings coincides with much of the Nasdaq bubble, allowing us to understand better how

satisfying the earnings or operating cash flow requirements. We note that the two exceptions are for relatively large firms, when compared to the NNM's requirements. 
market capitalization standards interplayed with a dramatically rising trading market. ${ }^{2}$ Finally, this was the period that introduced many internet and telecommunications technological innovations backed by venture capital funds. If, as Black and Gilson (1998) articulate, venture capital funds remain alive by backing new ventures and cashing out of "old" ventures, then the supply of possible new listings should increase substantially over this period. As we demonstrate, many of these "old" ventures came to market under the NNM market capitalization standard.

Our paper provides a number of contributions, a few that we describe here. First, our findings contribute to the understanding of the effects that different initial listing standards have on the types of firms that ultimately list. ${ }^{3}$ We find significant differences in firm performances and risks between NNM firms that list under a profitability standard against a market capitalization standard. These findings have implications for both the Nasdaq, which uses initial listing standards to ensure "investor protection"4 to investors and to investors themselves who may not be aware that firms list under different standards.

Second, our findings contribute to the growing literature on the unique characteristics that IPOs, new listings, and the Nasdaq market as a whole displayed in the late 1990s (see, for example, Hand (2000), Ritter and Welch (2002), Fama and French (2001, 2004)). We show that an inherent factor behind these characteristics is having market capitalization-based initial listing standards, which allowed a group of poor-performing, more risky firms to enter the NNM. In

\footnotetext{
${ }^{2}$ The height of the bubble, as measured by the Nasdaq Composite Index, was at the end of February 2000, in which the Index reached almost 4,700.

${ }^{3}$ This finding is analogous to the findings reported by Seguin and Smoller (1997), who document that when the Nasdaq doubled its required total assets (to $\$ 2$ million) and required capital and surplus (to $\$ 1$ million) in 1981, the proportion of stocks listing under $\$ 3$ per share declined in half (to 20.8\%) in 1983. They also show that new listings under $\$ 3$ per share performed substantially worse than new listings over $\$ 3$ per share and that the low-priced new listings were more apt to delist within five years. Interestingly, in 1992, the Nasdaq instituted a $\$ 3$ minimum bid price for initial listings.

${ }^{4}$ See Nasdaq Bulletin "Nasdaq Announces New Listing Requirements” dated August 25, 1997.
} 
contrast, firms that entered the NNM under a profitability standard were better performers and were less risky. Our performance factors include operating characteristics, long-run stock performance, and delisting rates. Riskiness is measured by the volatility of stock returns. Pástor and Veronesi (2004) find that Nasdaq stocks became more volatile at the height of the Nasdaq bubble. We find that market capitalization firms contributed to this phenomenon to a much greater degree than profitability firms.

Our findings are consistent with Fama and French's (2004) assertion that the supply curve for new lists shifted downward (increased) during the post-1979 time period. We argue that there are two interlocking explanations inherent to the 1997-2000 time period that are consistent with a further shift downward for our group of firms. From a behavioral finance standpoint, an "irrationally exuberant" market could sway investors to underweight the risks and overweight the expected returns of these IPOs, thus increasing the demand for these stocks. In particular, we point to the IPOs of Netscape in August 1995 and Amazon in May 1997 as two examples of extreme growth opportunities that could have influenced investors to misprice future Internet IPOs. Netscape's IPO went from an offering price of $\$ 28$ to a closing market price of $\$ 72$ on the first trading day. Amazon's split-adjusted price went from $\$ 1.50$ in May 1997 to \$53.54 in January 1998. From a supply-side standpoint, new technologies from this period, most notably in the internet and telecommunications industries, provided a pool of new, young firms eager to enter a national trading market. Thus, prior to these innovations, there was slack in the new-listings market, which the confluence of a market bubble and the new technologies took advantage of. As we note in this paper, $96.0 \%$ of all internet new listings, as provided by Loughran and Ritter's (2004) internet IPO database, entered the NNM through one of its market capitalization standards during our time period. 
The main conclusion of this paper is that initial listing standards endogenously determine the type of firm that entered the marketplace. During the market bubble of 1997-2000, the Nasdaq brought about a fundamental shift in the riskiness of new securities listed on the NNM because capital market standards were more easily obtained during hot IPO markets. Although, ex ante, this may not have been the Nasdaq's intention, we propose that the confluence of a market bubble, a new technology (the internet), and the newly-founded ability of start-up firms' investors to cash out exacerbated the entry into the NNM of these risky firms. From a policy standpoint, these findings are important because stock exchanges use initial listing requirements to ensure investors that newly-listed companies meet minimum standards of financial quality and protection (see Section 6(b)(5) of the 1934 SEC Act). From a research standpoint, studies examining firms may want to consider the standards by which the firms entered their respective markets.

Our analysis proceeds as follows. In section 2, we describe the economic conditions surrounding the new listing market from 1997 through 2000. Section 3 discusses the three alternative initial listing standards during our time period and compares them to the NYSE's initial listing requirements. Section 4 describes our sample selection and data. In Section 5, we examine the financial characteristics of market capitalization and profitability new listings at the time of listing. Section 6 examines these characteristics in event time. Section 7 looks at stock return performances - first day underpricing, long-run stock returns, and delistings. Section 8 examines return volatilities. Section 9 summarizes and presents some of our conclusions. 


\section{New Technologies, Venture Capital, and a Rising Nasdaq Market: An Increase in the Supply and Demand for New Listings}

Prior to the beginning of our sample date, August 22, 1997, conditions were ripe for an upward spike in the number of new listings entering the NNM. Between 1991 and 1997, the Nasdaq grew from 4,070 firms to 5,765 firms, and the percentage of high-technology firms rose from $23.1 \%$ in 1991 to $30.5 \%$ in $1997 .^{5}$ Using the SEC Edgar database, we find that the number of S-1 filings, filings usually associated with IPOs, increased from 43 in 1994 to 120 in 1995 to 996 in 1996 and 1,190 in 1997. Gompers and Lerner (2000) document a "fourteen-fold" increase in venture capital commitments between 1991 and 1997, compared to an inflationadjusted drop of 68\% between 1987 and 1991. Black and Gilson (1998) show similar increases and decreases in venture capital commitments during the same time period. They also demonstrate a substantial increase in the number of venture capital-backed IPOs between 1994 and 1996.

Thus, we propose that a large supply of potentially new listings were on the Nasdaq's horizon in late 1997. We also propose that as the Nasdaq market heated up over the 1997-2000 period, the demand for hi-tech new listings grew as well. Ex-post evidence supports this assertion. Schultz and Zaman (2001) report a mean underpricing of $80.7 \%$ for internet IPOs from 1996 through March 2000, compared to a mean underpricing of other IPOs of 21.6\%. Ofek and Richardson (2003) and Loughran and Ritter (2004) report first day mean returns of 96.24\% and $65 \%$ for internet firms between 1/1998 and 4/2000, and 1/1999 and 12/2000, respectively. The question remains, however, how these firms came to market. Although these papers do not

\footnotetext{
5 We classify a firm as "hi-tech" using Francis and Schippers' (1999) classification codes. Their hi-tech classification encompass all firms with primary three-digit SIC codes in drugs (283), computer and office equipment (357), electronics and other electrical equipment (360-368), telephone communications (481), computer and data processing services (737), and research, development, testing services (873).
} 
break down their samples by trading market, Fama and French (2004) report that more than $90 \%$ of the new lists of 1973-2001 are on the Nasdaq. We argue that the market capitalization listing standards of the Nasdaq were partially responsible for these observed phenomena.

\section{Nasdaq National Market Listing Standards}

All major markets (NYSE, AMEX, and Nasdaq) have initial and continuing listing standards. Although some papers argue that markets should drop listing requirements altogether (e.g., see Macey and O'Hara (2002)), stock markets impose listing standards on new and continuing firms to ensure a level of "quality and protection for investors" (Nasdaq 1996).

In the Nasdaq's own words:

The Nasdaq Stock Market is entrusted with the authority to preserve and strengthen the quality of and public confidence in its market. The Nasdaq Stock Market stands for integrity and ethical business practices in order to enhance investor confidence, thereby contributing to the financial health of the economy and supporting the capital formation process. Nasdaq issuers, from new public companies to companies of international stature, by being included in Nasdaq, are publicly recognized as sharing these important objectives of The Nasdaq Stock Market.

Nasdaq, therefore, in addition to applying the enumerated criteria set forth in the Rule 4300 and 4400 Series, will exercise broad discretionary authority over the initial and continued inclusion of securities in Nasdaq in order to maintain the quality of and public confidence in its market. ${ }^{6}$

A firm that initially fails to meet the market's initial listing standards is denied admission, while a currently traded firm that falls below the market's continuing requirements can and will be delisted eventually. These standards include quantitative financial thresholds for earnings, cash flows, revenues, or net assets, as well as qualitative governance requirements related to director and audit committee independence.

\footnotetext{
${ }^{6}$ NASD Manual, Section 4300, Qualification Requirements for Nasdaq Stock Market Securities, available on the Nasdaq website, www.nasdaq.com.
} 
The advent of alternative initial listing standards for NNM stocks arose in August 1981, when the SEC allowed the Nasdaq to designate some of its listed firms as "national market system" securities as of April 1982 on a experimental basis. ${ }^{7}$ Through 1984, the differences in alternatives related to trading parameters, not to quantitative financial standards. Beginning in January 1985, the NNM allowed firms to newly-list under a profitability standard or a "capital and surplus" standard. The Nasdaq increased its financial quantitative standards for the NNM in February 1989 and in August 1997. They also introduced an explicit market capitalization standard in August 1997.

Table 1 contains the NNM minimum quantitative financial standards that remained in place until June 29, 2001. As the table shows, there were three alternative standards. Under alternative 1, initial listings had to have, on the listing date, net tangible assets of $\$ 6$ million and in the last fiscal year or two of the last three fiscal years at least $\$ 1$ million pre-tax income. Under alternative 2, firms could enter the NNM if, on the listing date, they had a minimum net tangible assets $\$ 18$ million and an operating history of at least two years. Under alternative 3, newly-listed firms could list if they satisfied one of two requirements: (1) a minimum market capitalization of $\$ 75$ million, or (2) a minimum total asset base of $\$ 75$ million and a minimum of $\$ 75$ million in revenues.

Since alternative 1 is the only standard to require positive earnings, we call this the profitability initial listing standard. Since net tangible assets on the listing date include the proceeds kept by the firm, we designate alternative 2 as a market capitalization standard, albeit an implicit one. Alternative 3 is explicitly a market capitalization standard - the Nasdaq's notice

\footnotetext{
${ }^{7}$ See SEC Release No. 34-17549, February 17, 1981.
} 
to NASD members (November 1996) calls this alternative a "market capitalization test" for the national market. ${ }^{8}$

In contrast, the NYSE required almost all new lists to have positive pretax earnings over each of the three years prior to listing. The one exception throughout our time period is that firms with a global market capitalization of over $\$ 500$ million could list at the NYSE if they had three years of at least $\$ 25$ million in operating cash flows prior to listing. We regard both alternatives to be profitability initial listing standards. Further, as we noted above, beginning in June 1999, firms with a market capitalization of at least $\$ 1$ billion and $\$ 250$ million in the past year's revenues could also list without satisfying the earnings or operating cash flow requirements. Thus, the NYSE allowed very large firms to list without displaying a time-series history of profitability.

\section{Sample Selection and Data Description}

The data consist of new listings on the Nasdaq National Market Index between August 22, 1997 and June 30, 2000. August 22, 1997 coincides with the revised listing requirements. We end at June 30, 2000 as this approximately concurs with the end of the Nasdaq bull market and the associated hot IPO market, and also gives us a window of time to evaluate the effect of the new listings on the subsequent decline of the Nasdaq.

\subsection{Sample Selection and Classification of Firms}

Our goal is to examine the full sample of newly-listed, non-financial NNM firms between August 22, 1997 and June 30, 2000. As Panel A of Table 2 shows, we begin by identifying

\footnotetext{
${ }^{8}$ The rationale given by the Nasdaq for creating this alternative was to accommodate companies that "may fail to comply with the National Market net tangible assets test as a result of accounting for goodwill associated with various merger and acquisition activities, or as in the case of the telecommunications industry, significant depreciation." (Notice to NASD Members, November 1996) We do not examine this rationale in this paper.
} 
1,541 Nasdaq firms that first appear between these dates on the files of the Center for Research in Security Prices (CRSP). We eliminate 260 financial firms (SIC codes between 6000 and 6999), 89 firms with unit offerings (e.g., stock offerings combined with warrants), reverse LBOs, spin-offs, or secondary offerings, 168 firms that do not have a share code of 10 or 11 (ordinary common shares), and 62 firms that are listed on other exchanges or are tracking stocks. We augment our sample by adding 158 additional IPOs not in our sample from Fama and French (2004) that satisfy the criteria listed above. ${ }^{9}$ Since we require the firm's S-1 filing to determine the pro forma assets or net assets number, we remove 254 firms for which an S-1 filing was unavailable on www.SEC.gov or the required information to calculate pro forma net tangible assets was omitted from the filing. Finally, we eliminate 29 firms that we were unable to classify into any of the three Nasdaq listing requirements. In total, we have 837 new listings.

To verify our sample of NNM initial listings, we compare our sample to two IPO sources - the Thomson SDC Database and the sample of IPOs used by Fama and French (2004). As we show in Panel B of Table II, 572 firms in our final sample appear on both these databases. We include 100 firms appearing on Thomson SDC but not in the Fama and French (2004) sample, as well as 127 firms not on Thomson SDC but in Fama and French's (2004) database. Finally, we include 38 firms that satisfy the criteria laid out in Panel A, but do not appear in either the Thomson SDC or the Fama and French (2004) database.

We classify new NNM listings into three alternative classes, based on which initial standard they qualified under. Since the Nasdaq does not classify a new listing by alternative on the original listing date, or subsequently, we use the financial criteria as published by the Nasdaq to infer the listing type. Our classification is done sequentially using financial information from

\footnotetext{
${ }^{9}$ The Fama and French (2004) database has three sources: the Thomson SDC Data, which we use, Loughran and Ritter (1995) and Eckbo and Norli (2004).
} 
the fiscal year end just prior to the listing as well as information from the last available S-1 filing on or before the listing date. If a firm has net tangible assets of at least $\$ 6$ million and pretax income of at least $\$ 1$ million, we call it an Alternative 1 firm. Using the Nasdaq's definition, we define net tangible assets as total pro forma shareholder's equity (from the S-1 filing) minus goodwill (Compustat tem \#204). Pretax income is Compustat item \#170. If a firm does not satisfy these requirements, but has at least $\$ 18$ million of net tangible assets, we classify it as an Alternative 2 firm. ${ }^{10}$ If the firm does not satisfy the Alternative 1 or 2 requirements, but has at least $\$ 75$ million in both total pro forma assets (from the S-1 filing) and revenues (Compustat item \#12) or a market capitalization of $\$ 75$ million (from CRSP), this firm is designated an Alternative 3 firm. Market capitalization is the IPO price multiplied by the post-issue number of shares outstanding as shown on CRSP. ${ }^{11}$

\subsection{NNM New Listings Classified by Alternative Initial Listing Standards}

Table 3 presents the distribution of NNM new listings over the sample period. Panel A shows the listings under the three alternative listing requirements. Of the 837 new listings, $26.4 \%$ exceeded the alternative 1 hurdles, implying that about one-quarter of the new listings were profitable. In contrast, the vast majority, i.e., $70.3 \%$, of the new listings failed the alternative 1 listing requirements, but were able to list under the \$18 million net tangible assets requirement (alternative 2). Consistent with the Nasdaq's assertion that "few firms" would list under an explicit market capitalization standard, we find that only $3.3 \%$ of the new listings during this time period entered under the newly-instituted market capitalization standard.

\footnotetext{
${ }^{10}$ In addition, Alternative 2 firms need to have an operating history of at least two years. We do not have a reliable proxy for operating history. If we infer operating history from the available time series of information pre-listing, then 141 of our Alternative 2 firms will instead be classified as Alternative 3 firms. However, as we analyze Alternative 2 and 3 together, this distinction is not crucial.

${ }^{11}$ If IPO price is not available (for those firms that are non-IPOs), we instead use the lowest available price on that day from CRSP (amongst ASKHI, BIDLO and PRC).
} 
To examine the possible impact that raising funds in the market had on allowing these firms to exceed the minimum quantitative standards, we compare the classifications using historical numbers instead of pro-forma numbers. That is, we apply the initial listing standards on the data contained in the firms' latest quarterly filing prior to the offering and tabulate the number of firms that would have been able to enter the NNM without the benefit of receiving new proceeds from the public offering. Table 3, Panel B contains these results.

Of the 221 firms that entered the NNM under alternative 1, we find that without the proceeds from the offering, 151 firms $(68.3 \%)$ could have qualified based on their historical net tangible assets. The remaining 70 could not enter as alternative 1 as their net tangible assets fell below $\$ 6$ million, which obviously means that they could not list under alternative 2 as well which has a minimum net tangible assets requirement of $\$ 18$ million. However, 8 firms (3.6\%) had $\$ 75$ in both total assets and revenues which would allow them to list under alternative 3. The remaining 62 firms would not have been able to list on basis of their historical financials alone, though among them, 40 firms could have listed under alternative 3 as they had an initial market capitalization of \$ 75 million.

Of the 588 firms that entered the NNM under alternative 2, only $127(21.6 \%)$ had at least $\$ 18$ million of net tangible assets on their balance sheets prior to listing. A further 9 firms would have been able to enter under alternative three, with assets and revenues of greater than $\$ 75$ million. The remaining 452 alternative 2 firms could not have listed on the basis of their historical financials alone, though among them, 360 could have listed under alternative 3 as they had an initial market capitalization of $\$ 75$ million. Among the 28 alternative 3 firms, 15 met the requirements of having 75 million in sales and assets (historical or pro-forma), while the remaining 13 were able to list solely because of their market capitalization. 
To summarize, 527 of the 837 firms in our sample $(62$ alternative 1 firms +452 alternative 2 firms +13 alternative 3 firms) would not have been able to list based on their historical balance sheets and income statements alone. A vast majority of these firms (465 alternative 2 and 3 firms) entered the NNM under a market capitalization standard.

\subsection{NNM New Listings over Time}

In Table 3, Panel C, we present new listings by quarter. Concurrent with the Nasdaq index, which rose from 1,499 in August 1997 to 4,697 in February 2000, we notice a new listings boom during this period. The year 1999, in particular, produced 381 new listings, an increase of 115\% over 1998. Most significant, however, was the proliferation of market capitalization new listings during 1999 - 315 listings compared to only 107 in 1998 . We particularly note the shift away from profitability (Alternative 1) listings towards market capitalizations listings beginning in the third quarter of 1998. As late as the second quarter of 1998, almost one-half of NNM new listings were able to meet the profitability standard. From the third quarter of 1998 to the second quarter of 2000, at least $75 \%$ of new listings entered under a market capitalization standard, with the exception of one quarter - 1999-Q1. Thus, the boom market of $1998-2000$ is strongly associated NNM firms listing under a capitalization standard in lieu of a profitability one.

\subsection{NNM New Listings by Industry and Relation to the Internet IPO Boom}

Table 4 compares the industry composition of market capitalization new listings and profitability new listings, where industry is defined as the firm's primary three-digit SIC code. One industry, the three-digit SIC code, 737 - Computer and Data Processing Services yielded the plurality of market capitalization new lists - 273 new lists encompassing $44.3 \%$ of all market capitalization new listings. Notably, the same industry produced the most profitability new 
listings as well - $43(19.5 \%)$ new lists, but the concentration is far less. Using Francis and Schipper's (1999) broader definition of hi-tech stocks, we find that 416 market capitalization new listings (67.5\%) and 79 profitability new listings (35.7\%) are hi-tech. Thus, on a limited or broader scale, the market capitalization alternatives produced relatively more hi-tech new listings than the profitability alternative.

In Panel B of Table 4, we examine the degree to which the market capitalization listing standard contributed to the internet IPO boom of the late 1990s. Schultz and Zaman (2001) remark on how in late 1998 and early 1999, the number of internet companies that went public accelerated from before fall 1998. They refer to this phenomenon as a "rush" to go public.

We use Loughran and Ritter (2004)'s IPO Internet database, which has 424 Internet IPOs between August 22, 1997 and June 30, 2000. We were able to match 329 of these internet IPOs to our sample of new listings. ${ }^{12}$ Incredibly, $96 \%$ of these internet new listings entered the NNM under a market capitalization standard. Further, these 316 new listings represented $51.3 \%$ of all market capitalization new listings. In contrast, only 13 internet IPOs entered the NNM under a profitability standard, comprising just $4.0 \%$ of NNM new listings and $5.9 \%$ of all profitability new listings. Thus the market capitalization listing standard facilitated the entry of a large number of internet IPOs in the late 1990s.

\subsection{Relative Impact: Market Capitalization Listings as a Percentage of the Total NNM}

To assess the relative impact that the new listing standard had on the composition of the total NNM, we present, in Table 5, the proportion of all NNM-traded companies over time from fourth quarter 1997 through fourth quarter 2003 that originated as market capitalization new listings in the period we analyze, both in number and market value. We find that the percentage

\footnotetext{
${ }^{12}$ The remaining 95 firms, presumably, listed under the Nasdaq Small Cap umbrella or alternative exchanges.
} 
of NNM firms originating as market capitalization new lists rose steadily from $0.8 \%$ of the total number of all NNM-traded firms in 1997-Q4 to $11.3 \%$ in 2000-Q3. Afterwards, we note a steady deterioration in proportions to $8.4 \%$ in $2003-\mathrm{Q} 4$. This coincides with the rise and fall in the absolute number of all stocks trading on the NNM over this time period. One statistic worth noting is that from 2000-Q1, the height of the Nasdaq bubble, through 2001-Q4, at least $10 \%$ of NNM stocks originated as a market capitalization new listing in the period we analyze.

By 2000-Q1, just before the bursting of the Nasdaq bubble, market capitalization firms represent $17.6 \%$ of total market value. In dollars, we find an increase of $88 \%(\$ 1,098.2$ billion vs. $\$ 584.7$ billion) in market value between 1999-Q4 and 2000-Q1 alone. By 2003-Q4, market capitalization firms represent only $4.8 \%$ of the total NNM market value. Note that the rise and fall of the proportion of market capitalization firms is much more pronounced when measured in market value than in number of trading firms. As we later demonstrate, this is directly related to the market performances of these firms, which show dramatic increases and decreases, when compared to other listing types.

\section{Financial Characteristics of New NNM Listings by Type: Listing Date}

In this section, we examine whether market capitalization new listings have similar financial characteristics as profitability NNM new listings at the time of listing. This analysis augments papers by Fama and French (2001), Ljungqvist and Wilhelm (2003) and Loughran and Ritter (2004), who show relatively poor financials for all IPOs during the hi-tech bubble. We examine the impact that market capitalization new lists have on this phenomenon.

We focus on the following financial characteristics: total assets, growth in assets, revenues, growth in revenues, net income before extraordinary items, operating income (EBDIT) 
and cash flows from operations (CFO). ${ }^{13}$ We use annual Compustat data for the year closest to and prior to the listing date. Except when explicitly indicated the monetary effects of the offering proceeds are not included in these numbers. Since the distributions are bounded on the left by zero and are skewed to the right, we present and compare medians. Table 6 contains the medians for the market capitalization new listings and for the profitability new listings, the differences between the two, and z-statistics comparing for the difference being statistically different from zero. $^{14}$

\subsection{Firm Size}

Upon listing, market capitalization firms have significantly fewer assets and revenues than profitability new listings. The median total assets for market capitalization firms are $\$ 18.2$ million, compared to $\$ 34.9$ million for profitability new listings; the difference is significant at the $1 \%$ level $(\mathrm{z}$-stat $=-7.55)$. Market capitalization new listings have a median of $\$ 9.3$ million in revenues; profitability new listings have median revenues of $\$ 55.2$ million, which are significantly different at the $1 \%$ level $(\mathrm{z}$-stat $=-15.38)$. Thus, the new market capitalization listing requirement allowed a cohort of smaller firms to enter the NNM. The significant difference in assets is particularly startling given that firms that entered under the alternative 2 market capitalization standard vis-à-vis the profitability standard needed a higher threshold of net tangible assets ( $\$ 18$ million vs. $\$ 6$ million) to list.

Market capitalization firms also have lower book values of equity (\$-2.1 million) than profitability new listings (\$8.6 million), with the difference being significantly different at the $1 \%$ level $(z$-stat $=-10.91)$. When we take the offering into account, we find that the market

\footnotetext{
${ }^{13}$ The Compustat data items we use are Assets (\#6), Revenues (\#12), Net Income before extraordinary items (\#18), Operating Income (\#13), and Cash flows from operations (\#308).

${ }^{14}$ Very similar results are found with means instead of medians.
} 
value of the market capitalization new listings is higher ( $\$ 244.7$ million) than profitability listings (\$111.2 million, z-stat for difference $=5.37$ ), despite having far lower median assets and revenues. This latter result is a further reflection of the confluence between the Nasdaq hi-tech bubble and the increased demand by investors for new listings of these type of stocks.

\subsection{Profitability}

Consistent with the NNM listing requirements that only profitability firms have a minimum pre-tax income threshold, we find that profitability listings have a positive median nominal operating income (OI) of $\$ 8.4$ million on the fiscal year end preceding the listing date, whereas market capitalization listings have a negative average nominal operating income of $\$ 5.9$ million, significantly different at the $1 \%$ level $(z$-stat $=-18.83)$. The results for net income (NI) yield similar differences. Median NI is 3.9 million for profitability firms, and \$-8.2 million for other listings, significantly different at the $1 \%$ level ( $\mathrm{z}$-stat $=-21.42$ ).

To normalize income to firm size and to allow comparisons between our findings and Fama and French $(2001,2004)$, we present profitability scaled by total assets. The median OI/Assets is $21.5 \%$ for profitability firms, but is $-38.6 \%$ for market capitalization listings, significantly different at the $1 \%$ level (z-stat -20.43). The median NI/Assets is $10.4 \%$ for profitability firms, compared to $-48.6 \%$ for market capitalization listings, again significantly different at the $1 \%$ level $(\mathrm{z}$-stat $=-21.06)$. Thus, in relative terms, market capitalization listings are significantly less profitable than its counterparts on the NNM at the time of listing.

These results dovetail with Fama and French (2001), who show a deterioration in average EBIT/Assets from $6.7 \%$ for 1988 - 1992 to $3.7 \%$ for $1993-1998 .^{15}$ Our results indicate that the

\footnotetext{
${ }^{15}$ Although their samples contain NYSE, AMEX, and Nasdaq firms, Fama and French (2001) find that $85 \%$ of new lists between 1978 and 1998 originate on the Nasdaq, and that 90\% of the new lists in their sample for 1973-2000 are on the Nasdaq (Fama and French, 2004).
} 
deterioration of earnings for new lists in the listing year continues after 1998, the end of the Fama and French (2001) sample. As seen above, however, this decline can be traced to the firms being able to list under a market capitalization standard.

We also present the proportion of firms reporting losses (negative NI) at the time of listing. For our sample, $89.4 \%$ of market capitalization firms report losses compared to $0.9 \%$ of profitability firms, significantly different at the $1 \%$ level. ${ }^{16}$ To put these percentages in perspective, we compare them to several studies. Klein and Marquardt (2005) report that in 1997-2000, 38.8\% of all firms listed on the Compustat database have losses. Hence, market capitalization firms clearly hail from the extreme left tail of earnings distributions, while profitability firms, by definition, rarely show negative earnings. Ritter and Welch (2002) find that the proportion of new listings reporting losses rises from $37 \%$ in $1995-1998$ to $79 \%$ in 1999 2000 and then declines to $49 \%$ in 2001 . Since the majority of market capitalization firms listed in 1999 and 2000, we offer a possible explanation for this blip upwards in proportion of losses during this two year period. ${ }^{17}$

\subsection{Cash Flows from Operations}

Like earnings, operating cash flows (CFO) are negative for market capitalization firms. The median CFO for market capitalization new listings is $-\$ 4.6$ million, as opposed to 4.0 million for profitability new listings, significantly different at the $1 \%$ level $(\mathrm{z}$-stat $=-16.86)$. Median $\mathrm{CFO}$ /Assets for market capitalization firms is $-27.2 \%$, as against $11.6 \%$ for profitability new listings, significantly different at the $1 \%$ level $(\mathrm{z}$-stat $=-17.71)$. Further, while $82.3 \%$ of

\footnotetext{
${ }^{16}$ Profitability firms can report have losses because the standard requires them to be profitable (i.e. pretax income $>=\$ 1$ million) in either the year just prior to listing, or in two of the past three years.

${ }^{17}$ Ritter and Welch (2002) also report that the proportion of losses in IPOs was 19\% in 1980-1989 and $26 \%$ in $1990-$ 1994.
} 
market capitalization new listings report negative CFOs, only $14.0 \%$ of profitability new listings have negative CFOs.

In tandem, the earnings and cash flow findings provide a clear picture as to the effects of a profitability quantitative standard on new lists during this time period. Put differently, market capitalization initial listing standards allowed a class of firms with poor current performers to enter the NNM from August 1997 through June 2000.

\subsection{Asset and Revenue Growth Rates}

Fama and French (2004) demonstrate that although new lists in the 1990's were relatively unprofitable, they nevertheless displayed huge growth in assets (average annual growth rate of IPOs was 66.8\% in 1990-2000). Fama and French (2004) report this number for the fiscal year that includes the listing month. In this section, we report asset growth rates for the year prior to the listing date. The median one-year asset growth rates is $130.0 \%$ for market capitalization firms and $36.2 \%$ for profitability new listings $(\mathrm{z}$-stat $=6.38)$. Thus, while both groups experience expansive growth in assets prior to listing, market capitalization firms' assets grew at a much larger rate than profitability new listings. .

We also observe a much higher one-year growth rate on revenues for market capitalization new listing when compared to profitability listings. The median one-year revenue growth rate for market capitalization new listings is $110.0 \%$ percent, compared to $75.4 \%$ for profitability new listings, significantly different at the $1 \%$ level $(\mathrm{z}$-stat $=7.73)$. Thus, like assets, revenue growth is substantial for both cohorts of firms, but market capitalization firms' revenues grew at a quicker pace than their counterparts. 


\section{Financial Performance of NNM New Listings by Type: Four Years After Listing}

Fama and French (2004) show a steady deterioration in profitability, as measured by EBIT/Assets, for the first four years following an IPO for all IPOs that listed between 1990 and 2000. They analyze a sample of 374 non-financial IPOs from all exchanges that appear on CRSP and Compustat with non-missing data and find that average profitability declines from $3.1 \%$ in the year following the IPO to $0.2 \%$ in the following year to $-1.4 \%$ in the subsequent two years. In this section, we build on Fama and French's (2004) study by examining the financial performances of NNM new listings by type for the four years following the listing. Similar to Fama and French (2004), we present our results in event time, where year 1 is the year including the listing month and years 2 through 4 are the subsequent four years. Our sample period, however, begins in 1997, which is the latter part of Fama and French's (2004) sample period.

Table 7 presents the medians of the following four metrics: net income/assets (NI/Assets), operating income/assets (OI/Assets), CFO/assets, and revenues growth (RGR). ${ }^{18}$ For market capitalization new listings, net income is negative for years 1 through 4 . Median NI/Assets is $-16.3 \%$ in year 1, falls to $-31.0 \%$ in year 3 and "recovers" to $-19.6 \%$ percent in year 4. In contrast, performance firms continue to have positive, although deteriorating, net income over the four years following the new listing: the median NI/Assets for these firms is $5.8 \%$ for year 1, falling to $1.9 \%$ in year 4 . Testing for differences between the two groups yields significant differences, with z-statistics ranging from -9.47 to -17.96 .

This differential is equally dramatic for operating income. For all years, OI/Assets is negative for market capitalization firms, but is positive for profitability listings. Thus, market capitalization firms are relatively worse performers in terms of operating income than profitability firms. Further, when comparing our results to Fama and French (2004), we find that

\footnotetext{
${ }^{18}$ Very similar results are obtained with means instead of medians.
} 
market capitalization firms behave considerably worse than those reported for all IPOs between 1990 and 2000.

A similar story emerges when we examine cash flows from operations. $\mathrm{CFO}$ /Assets for market capitalization firms is negative for years 1-4, while it is positive for profitability firms for the same four years. Similar to relative operating income, relative cash flows are significantly lower at the $1 \%$ level for market capitalization firms for each year. Thus, we conclude that market capitalization firms are significantly less profitable in terms of earnings and cash flows than profitability new listings over their initial trading life cycle.

Revenue growth rates (RGR) ratios produce an interesting picture. Both groups show initial surges in revenue; $157.3 \%$ and $86.8 \%$ for market capitalization firms in years 1 and 2 respectively, and $40.3 \%$ and $27.2 \%$ for profitability new listings. In years 3 and 4 , these growth rates diminish dramatically, with market capitalization firms reporting a growth rate of just $3.2 \%$ in year 4 and profitability firms seeing a growth rate of $2.9 \%$ in year 4 . For years 1 and 2 , market capitalization firms have significantly higher revenue growth rates than profitability firms, but insignificantly different RGR in years 3 and 4.

The number of observations declines across event time for both groups, primarily due to delistings. The decline is much more precipitous for market capitalization firms (599 to 380, $37 \%$ ) as opposed to profitability firms (219 to $165,24 \%)$. We will examine this issue in greater detail when we analyze return performance.

To summarize, market capitalization firms perform poorly with respect to other new listings in the first four years after their initial listings on a variety of different dimensions including earnings profitability, and cash flow profitability. Market capitalization firms initially 
experience higher revenue growth rates than profitability new listings; however, by the third year after listing, the differentials in growth rates disappear and diminish greatly for both groups.

\section{Stock Return Performances}

\subsection{First Day Underpricing}

We begin by comparing the first day underpricing between market capitalization and profitability listings. As Table 8, Panel A shows, the mean day 1 return for market capitalization listings is $70.20 \%$ while the mean day 1 return for profitability new listings is $29.07 \%$, significantly different at the $1 \%$ level (t-stat 7.05 ). These results are influenced by outliers, as median returns are $34.69 \%$ for market capitalization listings and $13.27 \%$ for profitability new listings. Nevertheless, the medians are also significantly different from each other at the $1 \%$ level $(z$-stat $=5.29)$. We conclude there is a significant difference between groups with respect to first day underpricing returns, with the market capitalization group showing a greater degree of underpricing. ${ }^{19}$

Figure 1-A presents the underpricing for each standard by year of listing. As the figure shows, the amount of underpricing increased steadily for both groups as the Nasdaq index rose over time. Further, the relative differences in underpricing between profitability firms and market capitalization firms also rose steadily from 1997 through 1999, dropping somewhat in 2000. These yearly findings support the view that the Nasdaq market bubble and the Nasdaq's

\footnotetext{
${ }^{19} \mathrm{We}$ compare these results with prior studies that examine internet IPOs. Recall that $96.0 \%$ of all internet listings on the NNM between 1997-Q3 and 2000-Q2 were market capitalization listings, and that $51.3 \%$ of all market capitalization listings were internet companies. (Table 4, Panel B). Schultz and Zaman (2001) report a mean underpricing of $80.7 \%$ for internet IPOs from 1996 through March 2000, compared to a mean underpricing of other IPOs of 21.6\%. Ofek and Richardson (2003) and Loughran and Ritter (2004) report first day mean returns of $96.24 \%$ and $65 \%$ for internet firms between $1 / 1998$ and 4/2000, and 1/1999 and 12/2000, respectively. Thus, our first day return findings are consistent with these papers.
} 
listing standards go hand-in-hand in explaining some of the underpricing phenomena shown by others for IPOs in the late 1990s.

\subsection{Event-Time Returns}

Ritter and Welch (2002) present three-year buy and hold returns (BHARs) for IPOs (without the first day underpricing) by year from 1980 through 2001 and for subsets of these years. When using raw market returns, they find that the three year BHARs for stocks that went public in 1999 and 2000 were $-46.2 \%$ and $-67.2 \%$, respectively. In contrast, the average threeyear BHARs for 1990-1994 was $44.7 \%$ and for 1995-1998 was 20.8\%. Size-and-book-tomarket-adjusted BHARs report similar differentiations across time periods. Ritter and Welch (2002) conclude that long-run price performances for IPOs are not stationary. They present arguments for long-run underpricing in general, but state there is no plausible explanation for the 1999-2000 bubble collapse. We examine the long-run performances of market capitalization and profitability new listings to lend some insight into their findings.

We compute 3-year post-listing BHARs (without the first day underpricing) for market capitalization listings and profitability new listings using three expected return models to address the methodological issues surrounding tests of long-horizon stock performances. ${ }^{20}$ Initially, we calculate monthly raw stock returns. This gives an indication of how both market capitalization and profitability firms perform over time. Next, we compute monthly abnormal returns by subtracting from the listing's return (with dividend yield) two benchmark portfolios: the CRSP

\footnotetext{
${ }^{20}$ Barber and Lyon (1997), Kothari and Warner (1997) and Lyon, Barber and Tsai (1999) demonstrate how BHARs are affected by choices of weighting, market indices, and other benchmarks. Although Fama (1998) and Mitchell and Stafford (2000) argue that cumulative abnormal returns (CARS) and calendar-time abnormal returns (CTARs) are superior to BHARs in controlling for cross-sectional correlations, we do not calculate CARS or CTARS for the following reasons. Gompers and Lerner (2003) show that CARs for new listings are more likely to misrepresent performance than BHARs when returns are highly volatile - a condition that exists during our time period. Further, Ritter and Welch (2002) and Gompers and Lerner (2003) argue and show that the long-run performance for IPOs (new listings) is sensitive to the choice of tests and time periods.
} 
value-weighted index and the return on a size-based and book-to-market ratio based portfolio. The specifics of the methodologies are presented in the Appendix.

Table 8 Panel B presents raw cumulative stock returns by quarter for the three-year period following the listing date, exclusive of the initial underpricing. In terms of raw returns, market capitalization new listings outperform other new listings during the first two quarters; market capitalization listings rise $35.0 \%$ against $4.9 \%$ for profitability listings, a difference of $30.1 \%$, the difference significant at the $1 \%$ level $(\mathrm{t}$-stat $=3.96)$. By the third quarter, the differential in raw returns begins to diminish, turning negative in the $6^{\text {th }}$ quarter. By the end of the third year $\left(12^{\text {th }}\right.$ quarter), market capitalization firms earn a cumulative $-31.4 \%$ return, as opposed to a positive $30.6 \%$ earned by the profitability firms, a $-62.0 \%$ differential significant at the $5 \%$ level. Thus, when segregated by type, we find that the market capitalization new listings experience extremely negative long-run returns, whereas the profitability new listings have positive long-run returns.

In Panel $\mathrm{C}$, we present long-run performances relative to benchmark portfolios and find that the results are consistent with those reported for raw returns. Using CRSP market-adjusted returns, market capitalization firms outperform profitability listings over the first four quarter. The market-adjusted returns differential peaks after the second quarter at 30.6\%, significantly at the $1 \%$ level, then steadily declines over the next 2-1/2 years. At the end of three years, market capitalization firms experience a $-24.4 \%$ market-adjusted BHAR compared to $18.4 \%$ for the profitability listings, a $-42.8 \%$ difference that is significant at the $5 \%$ level. Size-and-book-tomarket-adjusted returns yield similar patterns and conclusions. ${ }^{21}$

\footnotetext{
${ }^{21}$ Eckbo and Norli (2004) claim that the underperformance of IPOs as a whole can be ascribed to lower risk, because IPOs tend to have greater liquidity as well as lower leverage. If, within our sample of new listings, market capitalization firms have greater liquidity and lower leverage, then this could explain some or all of the underperformance of market capitalization firms. We find insignificant differences in leverage (long-term-debt/total
} 
At this point, we offer three observations. First, Ritter and Welch (2002) report significantly negative average three-year BHARs for IPOs listing in either 1999 or $2000 .^{22}$ Since the vast majority of IPOs during these two years were market capitalization new listings, it appears that much of Ritter and Welch's (2002) results can be attributed to firms entering the NNM without being profitable. Second and similarly, profitability new listings actually showed a positive three-year return. Using raw returns, they rose $30.6 \%$ over three years. In fact, these listings outperform the market by $18.4 \%$ over the same time period (Panel C). Third, while market capitalization firms show a huge initial run-up in price six months after listing followed by a pronounced deterioration over the next two-and-a-half years, profitability new listings show a much steadier performance. Using raw returns, non-market capitalization stocks went up just $4.9 \%$ in the first six months and then went up a further $25.7 \%$ over the next two-and-a-half years. In contrast, market capitalization stocks rose by $35.0 \%$ in the first six months and then dropped $66.4 \%$ in the following two-and-a-half years. ${ }^{23}$

Figure 1-B presents the three-year raw BHARs by year of the listing. As the figure shows, there is a monotonic decrease in BHARs as we move from listings in 1997 through 2000. For 1997 and 1998 new listings, both profitability and market capitalization firms enjoyed positive three-year returns after listing. For 1999 listings, profitability firms had a slightly

assets) between market capitalization firms and profitability new listings. market capitalization firms do have greater liquidity (share turnover) in the first six quarters after the IPO, a period when market capitalization firms largely earn higher returns than profitability NNM listings, and not lower returns as would be expected for lower risk. After the first six quarters, the differences in liquidity between the market capitalization firms and profitability new listings are insignificant. Therefore, Eckbo and Norli's (2004) findings for all IPOs vs. the Nasdaq as a whole do not hold true for market capitalization vs. non-market capitalization NNM new listings.

${ }^{22}$ Ritter and Welch (2002) report raw return BHARs of $-46.2 \%$ and $-64.7 \%$, market-adjusted BHARs of $-32.9 \%$ and $-36.4 \%$, and size-and-book-to-market-adjusted BHARs of $-74.2 \%$ and $-42.6 \%$, respectively for 1999 and 2000 .

${ }^{23}$ The six month rise and subsequent fall of all of the NNM new listings are consistent with the expiration of the lockup period explanation offered by Ofek and Richardson (2003). Under this hypothesis, insiders are prohibited from selling more shares during a period following their company's IPO, thus limiting short-selling opportunities. This lockup period is negotiated between underwriter and the company, but usually lasts for about six months. After the expiration of the lockup period, insiders can sell and the firms' prices are shown to fall on and after that date. 
negative three-year return, but market capitalization returns showed negative returns in excess of $-40 \%$. For the 2000 new listings, both groups have negative three-year returns, with the market capitalization firms' returns exceeding $-80 \%$. These yearly returns shed light on the interplay among the Nasdaq bubble, new listings, and listing standards. As the Nasdaq market heated up, firms of lower quality came to market. However, the profitability initial listing standard appears to have had a mitigating effect on allowing these low quality firms to enter the NNM, whereas the market capitalization standards did little to prevent (perhaps even encouraging) these firms from listing.

We conclude that the initial listing standards by which NNM firms listed during the market bubble had enormous ramifications on the long-run stock performances of these firms. In particular, we demonstrate that firms that came to market during this period with a history of profitability (1) outperformed those firms that did not display this profitability and (2) were relatively more immune to the subsequent downturn that occurred in the Nasdaq after June 2000.

\subsection{Regression Analyses: Long-run Returns on Financial Quantitative Requirements}

In this section, we further examine the impact that various financial quantitative requirements had on the post-three-year returns for new listings through regression analyses. The dependent variable is the raw BHAR for the three year period after listing.

We include three types of predictive variables. PROFIT is a discrete variable that equals one for profitable firms, and zero otherwise. We predict a positive coefficient on PROFIT, as we expect profitability (positive pretax earnings) to be positively associated with long-run market returns, although we note that Hand (2000) found a negative relation between EPS and market value for internet firms during the market bubble. NTA_JUMP is the proportion of net tangible assets (NTA) that can be attributed to the inclusion of the listing proceeds, defined as (Pro forma 
NTA - Historical NTA)/Pro forma NTA. NTA_JUMP measures the market capitalization effect that listing on the NNM had on the firm's financials. We predict a negative coefficient on NTA_JUMP, as we expect firms whose asset base came primarily from the listing proceeds to be less viable in the long run. Our intuition can be seen in Figure 2, which shows the yearly difference in pro forma and historical net tangible assets in dollar terms (the numerator of NTA_JUMP). As the figure shows, the dollar difference went up dramatically from the first quarter of 1999 to the last quarter of 1999 and then stayed at the high amount through the first two quarters of 2000. This period coincides with Ritter and Welch's (2002) highly negative three-year long-run performance results for IPOs issued during 1999 and 2000.

IPORET is the one day underpricing that we document in section 7.1. IPORET is intended to measure the market's exuberance at purchasing the security during the market boom. We expect a negative coefficient on IPORET - basically, we predict that "what comes up, must come down" during a market bubble and bust. We also use three size variables, MSIZE the log of the market capitalization on day 1, ASIZE, the log of historical total assets, and SSIZE, the $\log$ of historical sales as control variables. We limit our sample to the 695 firms with available day 1 underpricing data as well as positive net tangible assets, which is used as a scaling factor for NTA_JUMP.

Table 9 contains the regression results. As we predict, three-year raw returns are positively related to whether the firm is profitable (PROFIT) and negatively related to the proportion of assets attributable to the offering (NTA_JUMP) and to the initial underpricing return (IPORET). Thus, we conclude that both listing standards and market conditions contributed to the rise and fall of NNM new listings in the late 1990s and early 2000s. Consistent with Seguin and Smoller (1997), who find a negative relation between delisting and 
initial market capitalization for Nasdaq firms in a prior period, the coefficient on MSIZE is marginally significant, suggesting that higher market capitalization leads to higher returns over time.

\subsection{Delistings by Groups}

Macey, O’Hara and Pompilio (2005) examine voluntary and involuntary delistings on the NYSE, and Nasdaq for 1995-2002. They find that the NYSE's involuntary delistings (those instigated by the exchange) ranged from 29 to 63 firms per year over this time period. In contrast, the Nasdaq's involuntary delistings were from 240 to 489 firms per year over the same time period. In relative terms, involuntary delistings as a percentage of total delistings ranged from $14 \%$ to $43 \%$ for NYSE firms, whereas they were from $49 \%$ to $64 \%$ for Nasdaq firms. These findings suggest that over their sample period, Nasdaq firms were more at risk to involuntarily delist than NYSE firms.

In Table 10, we examine the cumulative (by quarter) delisting frequencies for the market capitalization new listings and the profitability new listings for three-years following the listing. We begin by tracking all delistings (Panel A), and then examine poor-performance related delistings (Panel B). We define poor-performance delistings as those that either had a CRSP delisting code in the 400s (liquidations) or 500s (dropped by exchange), or had a negative cumulative return at the time of delisting and delisted due to a merger.

After one year, $7.0 \%$ of market capitalization new listings were delisted, compared to $2.7 \%$ of profitability new listings. After two years, $24.4 \%$ of market capitalization new listings were delisted against $13.1 \%$ for profitability new listings. And, after three years, $42.0 \%$ of market capitalization new listings eventually were delisted, which compares to $24.4 \%$ of profitability new listings. Differences in percentages are significant at the 5\% (one-year) and $1 \%$ 
(two- and three-year) levels, suggesting that market capitalization firms delisted more frequently than profitability firms.

When we consider poor performance related delistings, we see similar patterns. After one year, $3.4 \%$ of market capitalization new listings were delisted for poor performance reasons, as compared to $0.9 \%$ for profitability firms. After two years, the percentages are $19.3 \%$ and 7.2\% for market capitalization and profitability new listings, respectively. After three years, the percentages rise to $35.4 \%$ for market capitalization firms and $17.2 \%$ for profitability firms. Thus, after three years the percentage of market capitalization stocks that delist from the Nasdaq for poor performance is double that of the profitability group.

On a relative basis, the percentage of poor-performance related delistings to total delistings is $49 \%, 79 \%$ and $84 \%$ for years 1,2 and 3 for the market capitalization firms. For the

performance firms, the one-, two- and three-year percentages are 33\%, 55\% and $70 \%$. Therefore, in relative terms, market capitalization firms are more likely to delist for poor performance than profitability firms.

\subsection{Summary}

In summary, market capitalization firms have higher first-day underpricing premiums, negative three-year cumulative abnormal returns, and delist more frequently (for voluntary or poor-performance) when compared to profitability firms. These findings strongly support the view that eschewing a profitability initial listing standard requirement over the $1997-2000$ period resulted in a cadre of poor-performing firms. 


\section{Annualized Stock Return Volatilities}

The low profitability, changes in asset growth rates, high day 1 underpricing, and large price swings that we document for market capitalization firms suggest they are extremely risky. Pástor and Veronesi (2004) present a valuation model mapping uncertainty about average future profitability into stock return volatility. Consistent with these assertions, they show a pronounced upward shift in return volatility for the Nasdaq index from 1998 through 2001 compared to the previous thirty-five years. Our findings, along with Pástor and Veronesi (2004), suggest that market capitalization firms should exhibit higher return volatility than profitability new listings and the Nasdaq index as a whole.

We test for differences in return volatilities between market capitalization firms, profitability firms and the Nasdaq using Campbell et al.'s (2000) firm-specific volatility measure. We define $\sigma_{\text {Reti }}$ as the standard deviation of all available returns for firm $i$ in a given annual period, annualized by multiplying by $\sqrt{252}$. We take the average across the firms in the portfolio, including all firms with at least 50 valid return observations in the relevant annual period. $^{24}$

Table 11 contains the empirical results. In Panel A, we compare all new listings up till that point on the NNM with the Nasdaq index on a calendar-year basis for 1998-2004. In Panel B, we compare market capitalization new listings with profitability listings for 1998-2004. Panel C compares market capitalization and profitability new listings by event time.

\footnotetext{
${ }^{24} \mathrm{We}$ also measure return volatility at the portfolio level. Specifically, $\sigma_{\text {Port }}$ is the standard deviation of daily value weighted portfolio returns in a given year, annualized by multiplying by $\sqrt{252}$. Our results using this measure are qualitatively the same as the firm-level measure, and therefore, we do not report them. Since this methodology is similar to Pástor and Veronesi (2004), we also compare our Nasdaq index volatilities to theirs: like Pástor and Veronesi (2004), our Nasdaq index's volatility increases steadily, from $26.4 \%$ in 1998 to $48.8 \%$ percent in 2000, then declines steadily afterwards. In addition, our Nasdaq index volatilities are similar to what they report: $48.8 \%$ to $47 \%$ in 2000 and $34.5 \%$ to $34 \%$ in 2002 .
} 
As Panel A shows, from 1999 through 2004, all new listings on the NNM display higher return volatilities than the Nasdaq index. Consistent with Pástor and Veronesi (2004), the Nasdaq index's volatility rises between 1998 and 2000 and declines thereafter, although 2001 displays extremely high volatility as well. All new listings on the NNM follow the same trend, with volatility rising till 2000, remaining high in 2001 and falling thereafter. This rise and decline in volatility mirrors the number of new and surviving firms on the NNM, suggesting that more volatile firms left the NNM either through poor performance delisting or merger.

Panel B shows that market capitalization listings are significantly more volatile than profitability new listings throughout the entire time period. The differential in mean volatilities between market capitalization and profitability firms range from 7.8\% in 2004 to $36.8 \%$ in 2002 . As in Panel A, the peak volatilities for each group occur in 2000, with a mean firm-level return volatility of $133.9 \%$ for market capitalization firms and $99.6 \%$ for profitability firms. We also find (non-tabulated) that market capitalization firms are more volatile than the Nasdaq index for each year between 1998 and 2004. Thus, on a year to year basis, market capitalization listings exhibit significantly greater mean return volatility than profitability new listings and the Nasdaq as a whole.

We find similar results in event time. As Panel C shows, market capitalization firms have significantly higher return volatilities than profitability new listings for the first four years following listing. The differences are $36.5 \%$ for year 1, 38.9\% for year 2, 24.9\% for year 3 and $23.2 \%$. The difference in event year 5 is insignificant, presumably because of survivorship bias, especially in market capitalization firms.

Thus, as expected market capitalization stocks display greater stock return volatilities than profitability firms and the Nasdaq index, as a whole. These findings are consistent with 
market capitalization stocks being riskier than profitability stocks. They are also consistent with the view that market capitalization stocks contributed to the increased return volatilities for the Nasdaq during the market bubble, as documented by Pástor and Veronesi (2004).

\section{Summary and Conclusions}

We examine the role that different initial listing standards had on the increase in unprofitable, risky securities that entered the NNM between August 22, 1997, and June 30, 2000. We begin our analysis on August 22 1997, because on that date, the Nasdaq revised its initial listing standards. We end on June 30, 2000 to capture the full brunt of the precipitous rise in the Nasdaq composite index and to have a four-year window to examine the behavior of these firms.

Our analysis is based on the fact that the NNM had, in effect, two alternative sets of quantitative initial standards. Under one standard, newly-listed firms needed a minimum amount of pre-tax earnings to enter the NNM. Under the alternative standard(s), newly-listed firms needed either a minimum amount of pro-forma net tangible assets, pro-forma total assets or a minimum market capitalization upon listing. More telling, the alternative standard(s) have no profitability thresholds. We refer to the first standard as a profitability alternative, based on the required earnings. We refer to the second standard(s) as a market capitalization alternative, since a firm could enter the NNM by implicitly or explicitly raise enough proceeds from its offering to meet the NNM requirement. We also note that the NYSE required all firms to show three-years of profitability until June 1999, and then allowed only very large firms (market capitalization greater than $\$ 1$ billion) to enter without this requirement

We predict and show that during the Nasdaq bubble, many firms entered the NNM under a market capitalization standard. From August 1997 through June 2000, 688 firms qualified 
under the market capitalization standard, compared to 221 that qualified under the profitability standard. Of the 329 internet firms that newly-listed on the NNM over this time period, $96 \%$ were able to qualify under the market capitalization standard. At the end of the first quarter in 2000, market capitalization firms accounted for $17.6 \%$ of the entire market value of the Nasdaq. We attribute these phenomena as a blending of a high demand due to the Nasdaq bubble, new technologies being introduced over the time period, and an increase in the number of venture capital funds that wanted to cash out at high premiums.

We also demonstrate that it was the market capitalization new listings that primarily were responsible for the previously documented surge in the number of highly unprofitable, risky new listings that entered the marketplace during the late 1990s. We show this by comparing market capitalization firms to profitability firms over our time period in terms of financial characteristics, long-run firm performance and stock return volatilities. In all dimensions, we find market capitalization firms to be significantly different from profitability new listings. Market capitalization firms are extremely unprofitable in terms of income and operating cash flows when they list, and remain unprofitable over the next four years. In contrast, profitable new listings have positive income and operating cash flows when they list and earn positive earnings and operating cash flows over the next four years. Market capitalization firms initially experience higher revenue growth rates than profitability new listings; however, three years after listing, the differentials in growth rates either disappear or become more negative for market capitalization firms.

In terms of stock return performance, market capitalization firms significantly outperform profitability new listings for the first six months, but after three years, they significantly underperform profitability new listings. Using raw returns, profitability firms earn, on average, 
4.9\% after six months and $30.6 \%$ after three years. In contrast, market capitalization firms earn, on average, $35.0 \%$ after three months, but lose $41.4 \%$ after three years. These findings are robust to a variety of return specifications. Further, market capitalization firms involuntarily delist at much higher rates one-, two-, and three-years after listing vis-à-vis profitability firms. Thus, the negative stock performance for IPOs documented by Ritter and Welch (2002) and others for listings during the late 1990s appear to be attributable primarily to firms entering the NNM under a market capitalization standard and not a profitability standard. Similarly, the high number of involuntary Nasdaq delistings shown by Macey, O'Hara and Pompilio (2005) during this time appear to be skewed toward market capitalization firms but not profitability firms.

Finally, we find that for all years between 1998 and 2004, market capitalization firms experience higher stock return volatilities than the Nasdaq index and profitability new listings. Thus, the increase in return volatilities that Pástor and Veronesi (2004) document for the Nasdaq as a whole appear to be more pronounced for firms that entered the NNM under a market capitalization standard. 


\section{Appendix}

Methodologies for Computing Event-Time Returns

Returns are from CRSP. Compounding starts from the first available data point on CRSP, excluding first day underpricing. Firms are matched to the corresponding portfolio each year for calculating buy and hold returns for the control portfolio. As CRSP calculates its portfolios annually, the composition of the control portfolio for a given firm could change across time.

The buy-and-hold abnormal return, compounded monthly, for each firm is:

$$
\mathrm{BHAR}_{\mathrm{i}, \mathrm{t}}=\prod_{\mathrm{t}=1}^{\mathrm{N}}\left(1+\mathrm{R}_{\mathrm{it}}\right)-\prod_{\mathrm{t}=1}^{\mathrm{N}}\left(1+\mathrm{R}_{\mathrm{Bt}}\right)
$$

where:

$\begin{aligned} \mathrm{BHAR}_{\mathrm{it}} & = \\ \mathrm{R}_{\mathrm{it}} & = \\ \mathrm{R}_{\mathrm{Bt}} & = \\ \mathrm{N} & =\end{aligned}$

Buy and hold abnormal return for firm i over time period $t$

= firm i's raw return over time period $\mathrm{t}$

$$
=\quad \text { \# of days }
$$

The average buy-hold abnormal return for all firms over time period $t$ is:

$$
\overline{\mathrm{BHAR}_{\mathrm{t}}}=\frac{\sum \prod_{\mathrm{t}=1}^{\mathrm{N}}\left(1+\mathrm{R}_{\mathrm{it}}\right)-\prod_{\mathrm{t}=1}^{\mathrm{N}}\left(1+\mathrm{R}_{\mathrm{Bt}}\right)}{\mathrm{n}}
$$

where: $\overline{\mathrm{BHAR}_{\mathrm{t}}}=$ Average buy-hold abnormal return for all firms over time period $\mathrm{t}$

$$
\mathrm{n}=\# \text { of firms }
$$

The t-statistics for the $\overline{\mathrm{BHAR}}$ values are:

$$
t_{\text {BHAR }}=\frac{\overline{\text { BHAR }_{i, t}}}{\sigma\left(\text { BHAR }_{\mathrm{i}, \mathrm{t}}\right) / \sqrt{\mathrm{n}}}
$$

where: $\sigma\left(\mathrm{BHAR}_{\mathrm{i}, \mathrm{t}}\right)=$ Cross-sectional sample standard deviation of abnormal returns for the sample of $n$ firms.

For raw returns, $\mathrm{R}_{\mathrm{Bt}}$ is equal to zero. Market-adjusted returns are the raw buy-and-hold returns minus the buy-and- hold market return for the same compounding period, using the CRSP value-weighted index. Our final approach adjusts raw returns with a benchmark portfolio matched on size and book-to-market. The entire Nasdaq is divided each calendar year into size deciles based on market capitalization. Each decile is then further divided into quintiles of bookto-market, defined as the book value of equity divided by the market value of equity, both measured initially at the beginning of the listing month. This produces 50 benchmark portfolios. Each sample firm is then matched with one of the 50 portfolios formed in month t-1. The benchmark portfolios are newly constructed each year (Mitchell and Stafford (2000)).

If a sample firm does not survive the three-year post-event period, we use the delisting return for the firm in month $t$ and set the return on the firm and the return on the benchmark portfolio equal to zero. If there is no delisting return, we follow the methodology suggested by Shumway (1997). All but 39 new lists have a delisting return. 


\section{References}

Barber, Brad M., and John D. Lyon, 1997, Detecting long-run abnormal stock returns: The empirical power and specification of test statistics, Journal of Financial Economics 43, 341-372.

Bessembinder, Hendrik, 1999, Trade execution costs on Nasdaq and the NYSE: A postreform comparison, Journal of Financial Analysis 34, 387-407.

Black, Bernard S., and Ronald J. Gilson, 1998, Venture capital and the structure of capital markets: banks versus stock markets, Journal of Financial Economics 47, 243-277.

Campbell, John Y., Martin Lettau, Burton G. Malkiel, and Yexiao Xu, 2001, Have individual stocks become more volatile? An empirical exploration of idiosyncratic risk, Journal of Finance 56, 1-43.

Christie, William, and Roger Huang, 1994, Market structures and liquidity: A transaction data study of exchange listings, Journal of Financial Intermediation 3, 300-326.

Christie, William, and Paul Schultz, 1994, Why do NASDAQ market makers avoid odd-eight quotes? Journal of Finance 49, 1813-1840.

Dharan, Bala G., and David L. Ikenberry, 1995, The long-run negative drift of post-listing stock returns, Journal of Finance 50, 1547-1574.

Eckbo, B. Espen and Øyvind Norli, 2004, Liquidity risk, leverage, and long-run IPO returns, Journal of Corporate Finance, forthcoming.

Fama, Eugene F., 1998, Market efficiency, long-term returns, and behavioral finance, Journal of Financial Economics 49, 283-306.

Fama, Eugene F., and Kenneth R. French, 2001, Disappearing dividends: Changing firm characteristics or lower propensity to pay, Journal of Financial Economics 60, 3-43.

Fama, Eugene F., and Kenneth R. French, 2004, New lists: Fundamentals and survival rates, Journal of Financial Economics 73, 229-269.

Francis, Jennifer, and Katherine Schipper, 1999, Have financial statements lost their relevance? Journal of Accounting Research 37, 319-352.

Gompers, Paul A., and Josh Lerner, 2000, Money chasing deals? The impact of fund inflows on private equity valuations, Journal of Financial Economics 55, 281-325.

Gompers, Paul A., and Josh Lerner, 2003, The Really Long-Run Performance of Initial Public Offerings: The Pre-Nasdaq Evidence, Journal of Finance 58, 1355-1392. 
Hand, John, 2000, Profits, losses and the non-linear pricing of Internet stocks, Working Paper, University of North Carolina.

Klein, April, and Carol Marquardt, 2005, Fundamentals of Accounting Losses, Working Paper, New York University.

Kothari, S.P., and Jerold B. Warner, 1997, Measuring long-horizon security price performance, Journal of Financial Economics 43, 301-339.

Ljungqvist, Alexander, and William J. Wilhelm, Jr., 2003, IPO pricing in the dot-com bubble, Journal of Finance 58, 723-752.

Loughran, Tim, and Jay Ritter, 2004, Why has IPO underpricing changed over time? Financial Management, 5-37.

Lyon, John D., Brad M. Barber, and Chih-Ling Tsai, 1999, Improved methods of long-run abnormal stock returns, Journal of Finance, 165-201.

Macey, Jonathan and Maureen O'Hara, 2002, The economics of stock exchange listing fees and listing requirements, Journal of Financial Intermediation 11, 297-318.

Macey, Jonathan, Maureen O'Hara, and David Pompilio, 2005, Down and out in the stock market: The law and economics of the delisting process, Working Paper, Yale Law School and Cornell University.

Mitchell, Mark L., and Erik Stafford, 2000, Managerial decisions and long-term stock price performance, Journal of Business 73, 287-329.

Nasdaq, 1997, Nasdaq Announces New Listing Requirements, Nasdaq Stock Market Bulletin.

Nasdaq, 2002, The Nasdaq Stock Market: Historical and Current Listing Standards and Fees, Nasdaq Listing Qualifications Department.

Nasdaq Market Services, 1996, Introduction to the Nasdaq Stock Exchange, www.whiteandlee.com/nasdaq.html

Ofek, Eli, and Matthew Richardson, 2003, DotCom mania: The rise and fall of internet stock prices, Journal of Finance 58, 1113-1137.

Pástor, Ĺuboš, and Pietro Veronesi, 2004, Was there a Nasdaq bubble in the late 1990's? Working Paper, University of Chicago.

Ritter, Jay R., and Ivo Welch, 2002, A review of IPO activity, pricing, and allocations, Journal of Finance 57, 1795-1828. 
Schultz, Paul, and Mir Zaman, 2001, Do the individuals closest to internet firms believe they are overvalued?, Journal of Financial Economics 59, 347-381.

Seguin, P.J., and M.M. Smoller, 1997, Share price and mortality: An empirical evaluation of newly listed Nasdaq stocks, Journal of Financial Economics 45, 333-363.

Shumway, T, 1997, The Delisting Return Bias in CRSP Data, Journal of Finance 52, 327340. 


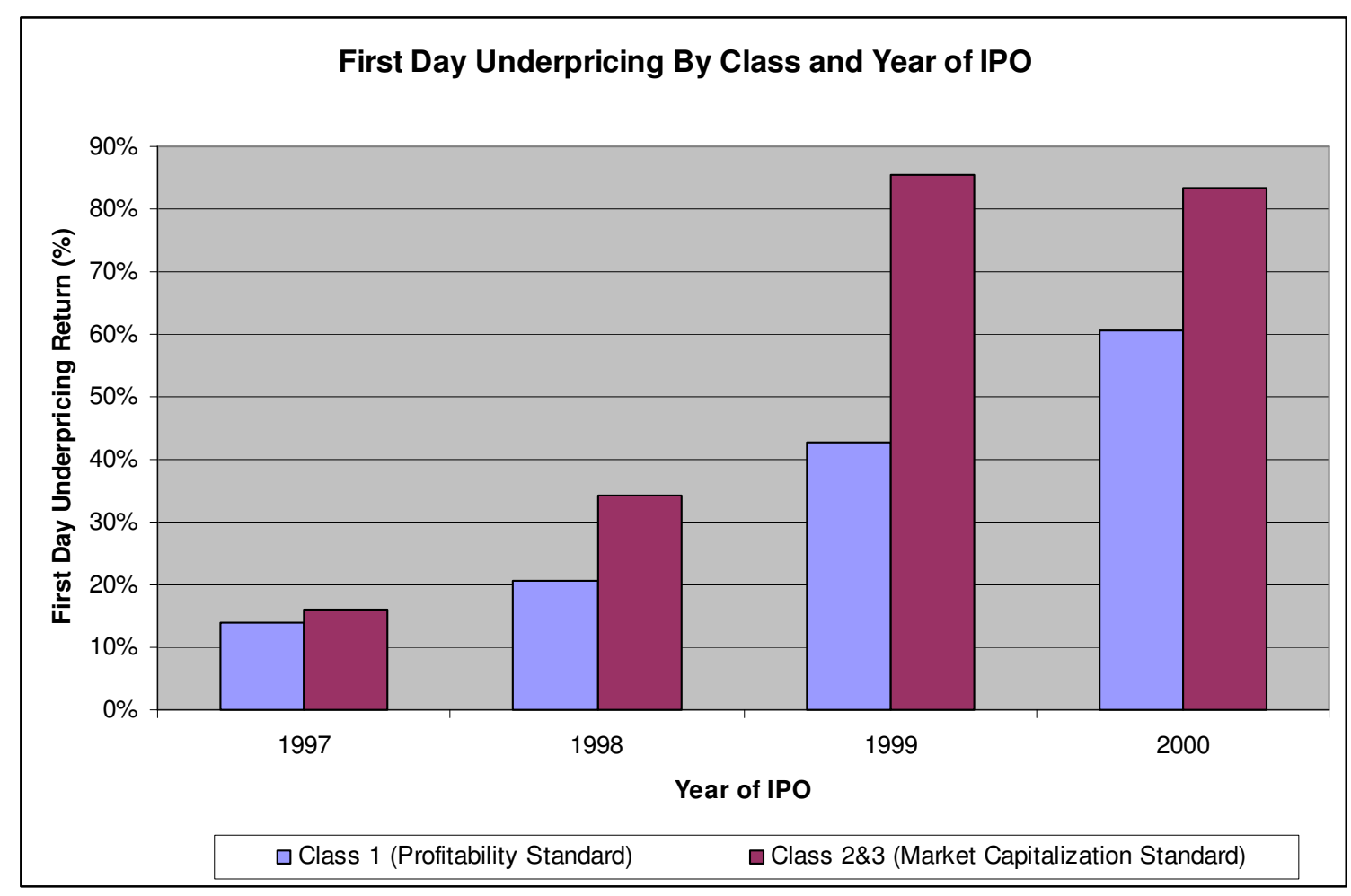

Figure 1-A

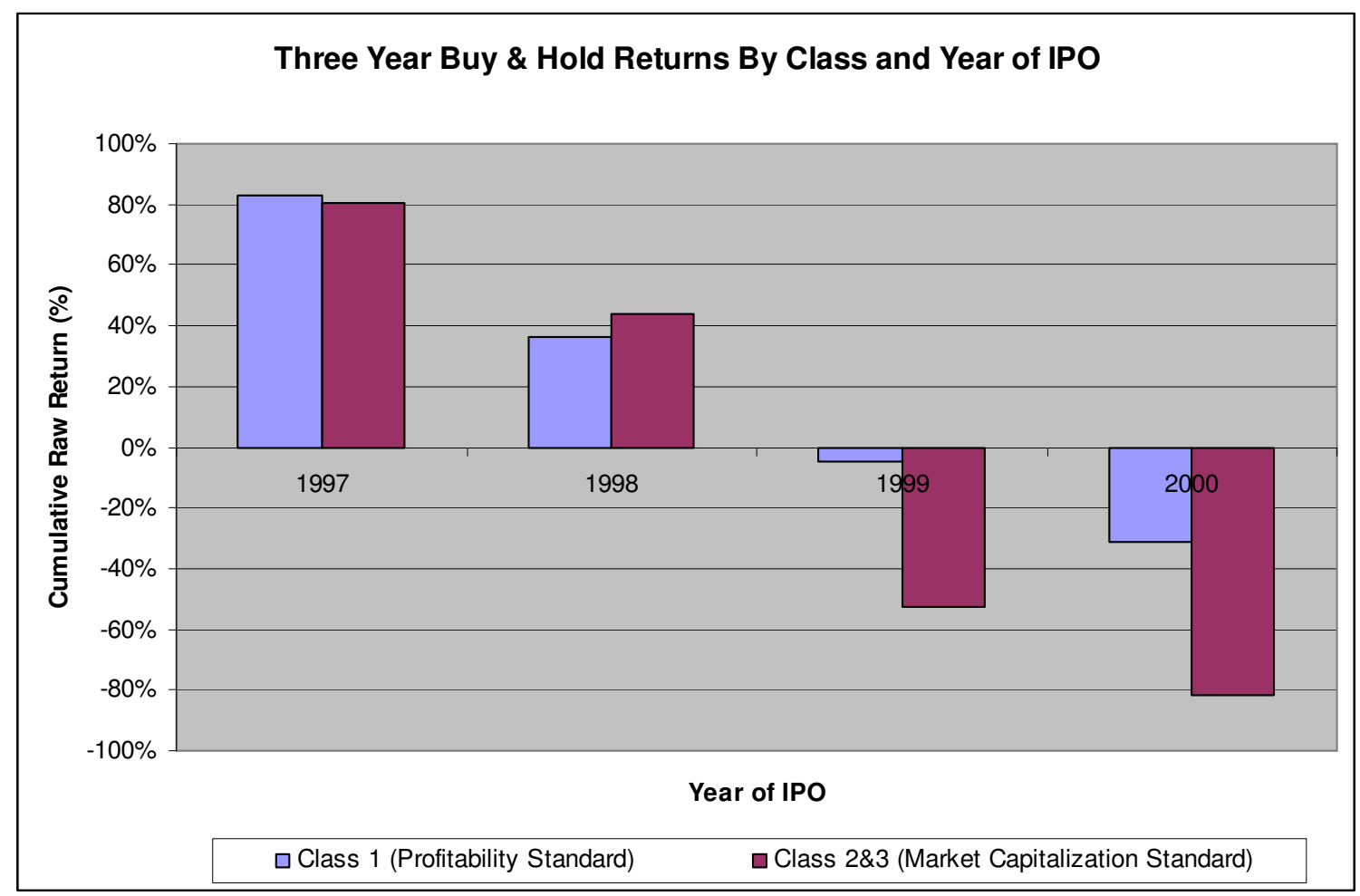

Figure 1-B 


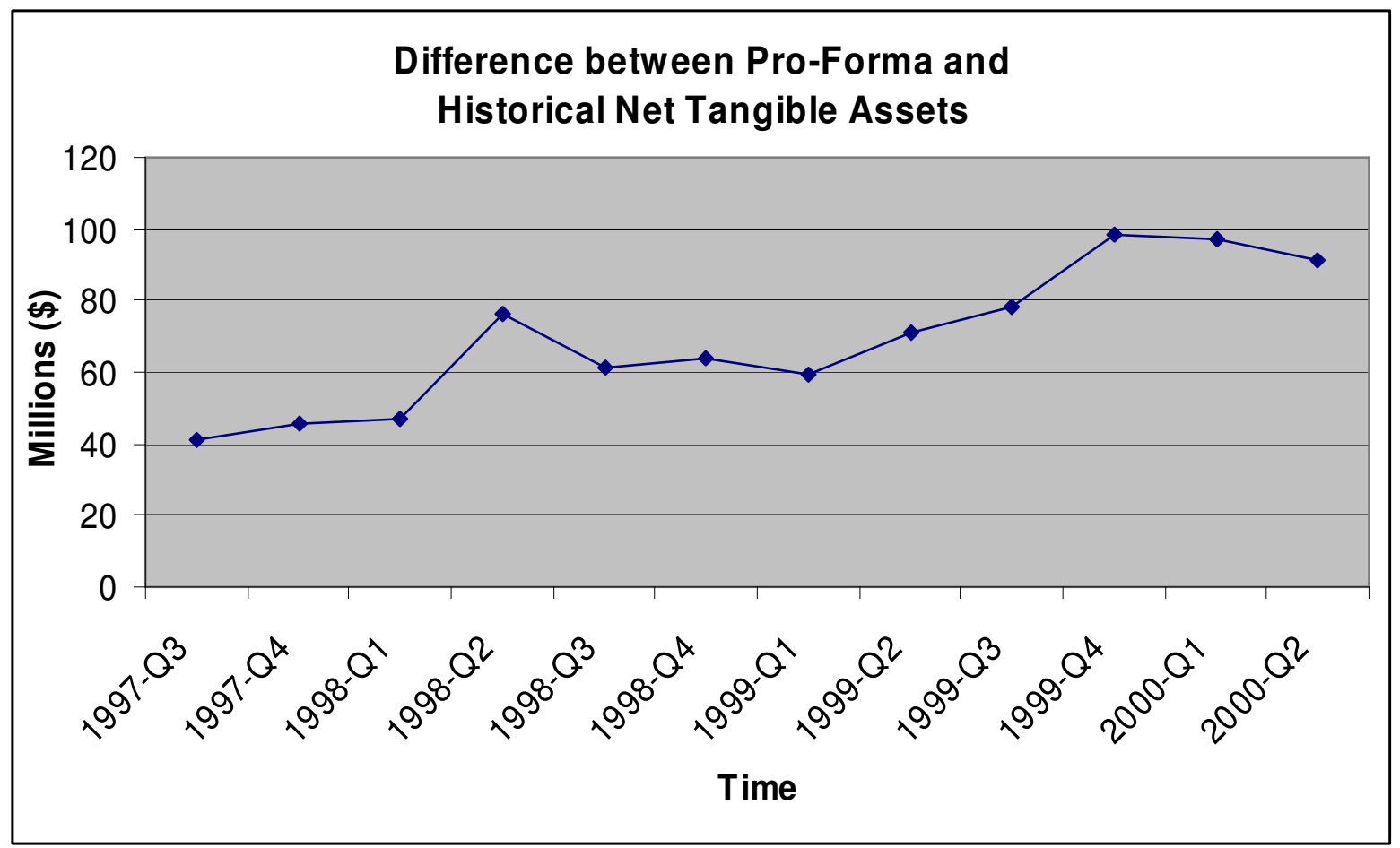

Figure 2 


\section{Table 1}

\section{Nasdaq National Market (NNM) Alternative Minimum Financial Standards for New Listings After August 22 1997}

This table presents the three alternative listing standards in effect between August 22, 1997 and June 28,2001 as published by the Nasdaq (2002). Over the time period, a firm could initially list on the NNM if it met one of the stated thresholds. We denote the three standards as Alternative 1, Alternative 2, and Alternativee 3. Nasdaq defines net tangible assets as assets minus liabilities minus goodwill. Market capitalization is number of shares outstanding times the price.

Alternative Initial Listing Standards from 8/22/97 Through 6/28/01

\begin{tabular}{lccc}
\hline & Alternative 1 & Alternative 2 & Alternative 3 \\
\hline Net Tangible Assets & $\$ 6,000,000$ & $\$ 18,000,000$ & - \\
& & - & - \\
$\begin{array}{l}\text { Pretax Income (in last fiscal year } \\
\text { or 2 of last 3 fiscal years) }\end{array}$ & $\$ 1,000,000$ & & \\
Operating History & - & 2 years & \\
\hline & & & $\$ 75,000,000$ \\
Market Capitalization & - & - & or \\
Total Assets & & & $\$ 75,000,000$ \\
and
\end{tabular}




\section{Table 2}

\section{Sample Selection and Data Availability}

This table presents the methods by which we construct our final sample of 837 new listings on the Nasdaq National Market (NNM) system between Aug $22^{\text {nd }} 1997$ and June $30^{\text {th }}$ 2000. Panel A presents a summary of how the sample was selected. Panel B links our sample with samples of other recent studies examining new listings.

Panel A: Sample Selection

Criterion

Number

of firms

1.) Firms that started listing on the Nasdaq between Aug 22, 1997 and June 30, 2000, as identified by CRSP.

MINUS: Firms with SIC Code between 6000 and 6999 (financial firms).

1,541

.) Non-Financial Firms satisfying 1.)

1,281

MINUS: Firms that are deleted because their shares were units, the IPO was a reverse LBO, spin-off or not the first IPO.

3.) Firms that are not units, reverse LBOs, spin-offs or non-first IPOs satisfying 2.) $\quad 1,192$

MINUS : Firms with share codes that are not 10 or 11 (ordinary common stock) (168)

4.) Ordinary common stock listings satisfying 3.)

1,024

MINUS : Firms that are also listed in other exchanges and tracking stocks

PLUS: Additional IPOs identified in Fama and French (2004) that are not in our sample

6.) Augmented Sample satisfying 5.)

1,120

MINUS : Firms for which data from S-1 was unavailable

$\underline{(254)}$

7.) Augmented Sample satisfying 6.) with $S-1$ data

866

MINUS : Firms that were unclassified or small cap stocks(29)

$(\underline{29)}$

FINAL SAMPLE

$\underline{837}$

Panel B: Classification of Firms by Data Availability

\begin{tabular}{lcc}
\hline Category & $\begin{array}{l}\text { Number of } \\
\text { firms }\end{array}$ & Proportion \\
\hline $\begin{array}{l}\text { 1. Firms Identified as IPO by us (using Thomson SDC Data) as well } \\
\text { as by Fama and French (2004) }\end{array}$ & 572 & $68.3 \%$ \\
$\begin{array}{l}\text { 2. Firms Identified as IPO by us (using Thomson SDC Data), but not } \\
\text { Fama and French (2004) }\end{array}$ & 100 & $11.9 \%$ \\
3. Firms Identified as IPO by Fama and French (2004), but not by us & 127 & $15.2 \%$ \\
4. Firms not identified as IPO by either of us (non-IPO firms) & $\underline{38}$ & $\underline{4.5 \%}$ \\
FINAL SAMPLE & $\underline{837}$ & $\underline{100 \%}$ \\
\hline
\end{tabular}




\section{Table 3}

\section{Classification of NNM New Listings Based on Alternative Listing Requirements}

This table classifies firms into Alternative 1, Alternative 2, or Alternative 3 based on the three alternative initial NNM financial listing requirements in effect between August 22, 1997 and June 30, 2000. We classify firms sequentially. If, at listing time, a firm has net tangible assets $>=\$ 6$ million and pretax income $>=\$ 1$ million, we call it an Alternative 1 firm. If not, a firm with net tangible assets $>=\$ 18$ million is classified as an Alternative 2 firm. If the firm does not satisfy the Alternative 1 or 2 requirements, but has at least $\$ 75$ million in total assets and revenues, or a market capitalization of $\$ 75$ million, we call it an Alternative 3 firm. Panel A presents the classifications for the full sample of 837 NNM new listings. Panel B compares the categorization of the listing using pro-forma net tangible assets with what the categorization would have been if historical (last 10-K) net tangible assets were used instead. Panel $\mathrm{C}$ presents the classifications by quarter.

Panel A: Classification of Firms Based on Alternative NNM Listing Requirements, using "pro-forma" numbers

\begin{tabular}{lll}
\hline Alternative & Number of firms & Proportion \\
\hline Alternative 1 & 221 & $26.4 \%$ \\
Alternative 2 & 588 & $70.3 \%$ \\
Alternative 3 & $\underline{28}$ & $\underline{3.3 \%}$ \\
Total & 837 & $100 \%$ \\
\hline
\end{tabular}

Panel B: Comparison of Classification Using Pro-Forma and Historical Numbers

\begin{tabular}{|c|c|c|c|c|c|}
\hline ALTERNATIVE & $\begin{array}{c}\text { Alt. } 1 \\
\text { (Historical) }\end{array}$ & $\begin{array}{c}\text { Alt. } 2 \\
\text { (Historical) }\end{array}$ & $\begin{array}{c}\text { Alt. } 3 \\
\text { \$ } 75 \text { MM Sales \& } \\
\text { Assets (Historical) }\end{array}$ & $\begin{array}{c}\text { Alt. } 3 \\
\text { \$75 MM Market } \\
\text { Cap }\end{array}$ & $\begin{array}{l}\text { Unable } \\
\text { to List }\end{array}$ \\
\hline $\begin{array}{l}\text { Alternative } 1 \\
\text { (Pro-Forma) }\end{array}$ & 151 & 0 & 8 & 40 & 22 \\
\hline $\begin{array}{l}\text { Alternative } 2 \\
\text { (Pro-Forma) }\end{array}$ & 0 & 127 & 9 & 360 & 92 \\
\hline $\begin{array}{l}\text { Alternative 3: } \\
\text { \$ } 75 \mathrm{MM} \\
\text { Sales \& Assets } \\
\text { (Pro-Forma) }\end{array}$ & 0 & 0 & 15 & 0 & 0 \\
\hline $\begin{array}{l}\text { Alternative 3: } \\
\text { \$ } 75 \text { MM } \\
\text { Market Cap }\end{array}$ & 0 & 0 & 0 & 13 & 0 \\
\hline
\end{tabular}




\begin{tabular}{|c|c|c|c|c|}
\hline \multicolumn{5}{|c|}{ Panel C: Number and Proportion of Firms by Alternative across Time } \\
\hline Quarter & Alternative 1 & Alternative 2 & Alternative 3 & Total \\
\hline $1997-$ Q3 & $\begin{array}{c}17 \\
(68.0 \%)\end{array}$ & $\begin{array}{c}8 \\
(32.0 \%)\end{array}$ & $\begin{array}{c}0 \\
(0.0 \%)\end{array}$ & $\begin{array}{c}25 \\
(100.0 \%)\end{array}$ \\
\hline $1997-$ Q4 & $\begin{array}{c}46 \\
(51.1 \%)\end{array}$ & $\begin{array}{c}42 \\
(46.7 \%)\end{array}$ & $\begin{array}{c}2 \\
(2.2 \%)\end{array}$ & $\begin{array}{c}90 \\
(100.0 \%)\end{array}$ \\
\hline $1998-\mathrm{Q} 1$ & $\begin{array}{c}22 \\
(43.1 \%)\end{array}$ & $\begin{array}{c}28 \\
(54.9 \%)\end{array}$ & $\begin{array}{c}1 \\
(2.0 \%)\end{array}$ & $\begin{array}{c}51 \\
(100.0 \%)\end{array}$ \\
\hline $1998-\mathrm{Q} 2$ & $\begin{array}{c}37 \\
(47.4 \%)\end{array}$ & $\begin{array}{c}37 \\
(47.4 \%)\end{array}$ & $\begin{array}{c}4 \\
(5.1 \%)\end{array}$ & $\begin{array}{c}78 \\
(100.0 \%)\end{array}$ \\
\hline $1998-\mathrm{Q} 3$ & $\begin{array}{c}9 \\
(25.0 \%)\end{array}$ & $\begin{array}{c}27 \\
(75.0 \%)\end{array}$ & $\begin{array}{c}0 \\
(0.0 \%)\end{array}$ & $\begin{array}{c}36 \\
(100.0 \%)\end{array}$ \\
\hline $1998-\mathrm{Q} 4$ & $\begin{array}{c}2 \\
(16.7 \%)\end{array}$ & $\begin{array}{c}9 \\
(75.0 \%)\end{array}$ & $\begin{array}{c}1 \\
(8.3 \%)\end{array}$ & $\begin{array}{c}12 \\
(100.0 \%)\end{array}$ \\
\hline $1999-\mathrm{Q} 1$ & $\begin{array}{c}17 \\
(37.8 \%)\end{array}$ & $\begin{array}{c}25 \\
(55.6 \%)\end{array}$ & $\begin{array}{c}3 \\
(6.7 \%)\end{array}$ & $\begin{array}{c}45 \\
(100.0 \%)\end{array}$ \\
\hline $1999-\mathrm{Q} 2$ & $\begin{array}{c}16 \\
(15.5 \%)\end{array}$ & $\begin{array}{c}82 \\
(79.6 \%)\end{array}$ & $\begin{array}{c}5 \\
(4.9 \%)\end{array}$ & $\begin{array}{c}103 \\
(100.0 \%)\end{array}$ \\
\hline $1999-\mathrm{Q} 3$ & $\begin{array}{c}15 \\
(13.3 \%)\end{array}$ & $\begin{array}{c}94 \\
(83.2 \%)\end{array}$ & $\begin{array}{c}4 \\
(3.5 \%)\end{array}$ & $\begin{array}{c}113 \\
(100.0 \%)\end{array}$ \\
\hline $1999-\mathrm{Q} 4$ & $\begin{array}{c}18 \\
(15.0 \%)\end{array}$ & $\begin{array}{c}99 \\
(82.5 \%)\end{array}$ & $\begin{array}{c}3 \\
(2.5 \%)\end{array}$ & $\begin{array}{c}120 \\
(100.0 \%)\end{array}$ \\
\hline $2000-\mathrm{Q} 1$ & $\begin{array}{c}10 \\
(10.6 \%)\end{array}$ & $\begin{array}{c}83 \\
(88.3 \%)\end{array}$ & $\begin{array}{c}1 \\
(1.1 \%)\end{array}$ & $\begin{array}{c}94 \\
(100.0 \%)\end{array}$ \\
\hline $2000-\mathrm{Q} 2$ & $\begin{array}{c}12 \\
(17.1 \%)\end{array}$ & $\begin{array}{c}54 \\
(77.1 \%)\end{array}$ & $\begin{array}{c}4 \\
(5.7 \%)\end{array}$ & $\begin{array}{c}70 \\
(100.0 \%)\end{array}$ \\
\hline
\end{tabular}


Table 4

\section{Industry Distribution of Market Capitalization New Listings and Profitability New Listings}

This table presents NNM new listings by industry defined by the firm's primary 3-digit SIC code. Panel A contains the industry distribution for 616 market capitalization new listings and 221 profitability new listings. Market capitalization new listings are those that entered the NNM under alternatives 2 or 3 . Profitability new listings are those that entered the NNM under alternative 1. Only industries which constituted at least $1 \%$ of market capitalization listings are presented. The list is sorted by descending order of the industries' contribution to the total market capitalization listings. For Panel B, we identify internet firms from amongst our sample, using Loughran and Ritter (2004)'s internet IPO database. We were able to match 329 Internet firms from the Loughran and Ritter sample that were listed in the time period analyzed in this paper (between Aug $22^{\text {nd }} 1997$ and June $30^{\text {th }} 2000$ ). We classify these internet firms by listing type.

Panel A: Industry Distribution of New Listings by Listing Type

\begin{tabular}{llcccc}
\hline & & \multicolumn{2}{c}{ Market Capitalization } & \multicolumn{2}{c}{ Profitability } \\
& & New Listings & New Listings \\
\hline $3-$ Digit SIC & Description & Number & Proportion & Number & Proportion \\
\hline 737 & Computer and Data Processing Services & 273 & $44.3 \%$ & 43 & $19.5 \%$ \\
481 & Telephone Communication & 41 & $6.7 \%$ & 4 & $1.8 \%$ \\
738 & Misc. Business Services & 38 & $6.2 \%$ & 4 & $1.8 \%$ \\
367 & Electronic Components and Accessories & 29 & $4.7 \%$ & 14 & $6.3 \%$ \\
283 & Drugs & 23 & $3.7 \%$ & 8 & $3.6 \%$ \\
366 & Communications Equipment & 22 & $3.6 \%$ & 4 & $1.8 \%$ \\
873 & Research and Testing Services & 17 & $2.8 \%$ & 3 & $1.4 \%$ \\
357 & Computer and Office Equipment & 11 & $1.8 \%$ & 3 & $1.4 \%$ \\
483 & Radio and Television Broadcasting & 10 & $1.6 \%$ & 3 & $1.4 \%$ \\
384 & Medical Instruments \& Supplies & 9 & $1.5 \%$ & 0 & $0.0 \%$ \\
596 & Non-store Retailers & 9 & $1.5 \%$ & 3 & $1.4 \%$ \\
731 & Advertising & 9 & $1.5 \%$ & 0 & $0.0 \%$ \\
874 & Management \& Public Relations & 9 & $1.5 \%$ & 5 & $2.3 \%$ \\
382 & Measuring and Controlling Devices & 8 & $1.3 \%$ & 5 & $2.3 \%$ \\
573 & Radio, Television, \& Computer Stores & 8 & $1.3 \%$ & 0 & $0.0 \%$ \\
594 & Misc. Shopping Goods Stores & 7 & $1.1 \%$ & 3 & $1.4 \%$ \\
& Rest & 93 & $15.1 \%$ & $\underline{119}$ & $53.8 \%$ \\
& Total & 616 & & 221 & \\
\hline
\end{tabular}

Panel B: Internet New Listings According to Listing Type

\begin{tabular}{llcc}
\hline $\begin{array}{l}\text { New Listing } \\
\text { Type }\end{array}$ & Number & \% of All Internet New Listings & \% of Type that are Internet Firms \\
\hline Profitability & 13 & $4.0 \%$ & $5.9 \%$ (of 221) \\
Market & $\underline{316}$ & $\underline{96.0 \%}$ & $51.3 \%$ (of 616) \\
$\begin{array}{l}\text { Capitalization } \\
\text { Total }\end{array}$ & 329 & $100 \%$ & \\
\hline
\end{tabular}


Table 5

\section{Market Capitalization Based New Listings as a Proportion of NNM over Time}

This table presents both the number of market capitalization listings (post August $25^{\text {th }}$ 1997) and the percentage of the total NNM that market capitalization listings (originally entered the NNM under alternatives 2 or 3 ) are between the fourth quarter of 1997 (1997 - Q4) and the fourth quarter of $2003(2003-Q 4)$. The left-side of the table presents the number of market capitalization firms traded at the end of the quarter and its proportion (\% Mkt.Cap.Firms) of total NNM firms at the end of the quarter. The right-side of the table presents the total market value of market capitalization firms in billions of dollars at the end of the quarter and its proportion (\% Mkt. Cap. Firms) of the total market value of the NNM at the end of the quarter.

\begin{tabular}{|c|c|c|c|c|c|c|}
\hline $\begin{array}{l}\text { Time } \\
\text { Period }\end{array}$ & $\begin{array}{c}\text { Number of } \\
\text { NNM } \\
\text { Firms }\end{array}$ & $\begin{array}{c}\text { Number of } \\
\text { Market } \\
\text { Capitalization } \\
\text { Firms } \\
\text { (post 8/25/1997) }\end{array}$ & $\begin{array}{l}\text { \% Mkt. } \\
\text { Cap. } \\
\text { Firms }\end{array}$ & $\begin{array}{c}\text { Total NNM } \\
\text { Market Value } \\
\text { (\$ Billion) }\end{array}$ & $\begin{array}{c}\text { Total Market } \\
\text { Value of Market } \\
\text { Capitalization } \\
\text { Firms } \\
\text { (post } 8 / 25 / 1997) \\
\text { (\$ Billion) }\end{array}$ & $\begin{array}{l}\text { \% Mkt. } \\
\text { Cap. } \\
\text { Firms }\end{array}$ \\
\hline $1997-$ Q4 & 5484 & 42 & $0.8 \%$ & 1832.4 & 8.8 & $0.5 \%$ \\
\hline $1998-\mathrm{Q} 1$ & 5405 & 73 & $1.4 \%$ & 2180.6 & 19.6 & $0.9 \%$ \\
\hline $1998-\mathrm{Q} 2$ & 5370 & 107 & $2.0 \%$ & 2273.5 & 35.0 & $1.5 \%$ \\
\hline $1998-\mathrm{Q} 3$ & 5245 & 147 & $2.8 \%$ & 2028.9 & 33.7 & $1.7 \%$ \\
\hline $1998-\mathrm{Q} 4$ & 5068 & 149 & $2.9 \%$ & 2606.7 & 50.9 & $2.0 \%$ \\
\hline 1999 - Q1 & 4928 & 167 & $3.4 \%$ & 2871.0 & 81.0 & $2.8 \%$ \\
\hline 1999 - Q2 & 4877 & 228 & $4.7 \%$ & 3165.5 & 177.1 & $5.6 \%$ \\
\hline $1999-$ Q3 & 4829 & 325 & $6.7 \%$ & 3320.2 & 259.4 & $7.8 \%$ \\
\hline 1999 - Q4 & 4808 & 421 & $8.8 \%$ & 5218.2 & 584.7 & $11.2 \%$ \\
\hline $2000-\mathrm{Q} 1$ & 4811 & 480 & $10.0 \%$ & 6237.1 & 1098.2 & $17.6 \%$ \\
\hline $2000-\mathrm{Q} 2$ & 4846 & 544 & $11.2 \%$ & 5620.0 & 585.5 & $10.4 \%$ \\
\hline $2000-\mathrm{Q} 3$ & 4862 & 551 & $11.3 \%$ & 5359.6 & 913.6 & $17.0 \%$ \\
\hline $2000-\mathrm{Q} 4$ & 4699 & 527 & $11.2 \%$ & 3611.4 & 388.2 & $10.7 \%$ \\
\hline $2001-\mathrm{Q} 1$ & 4557 & 499 & $11.0 \%$ & 2698.5 & 264.6 & $9.8 \%$ \\
\hline $2001-\mathrm{Q} 2$ & 4356 & 463 & $10.6 \%$ & 3159.1 & 226.8 & $7.2 \%$ \\
\hline $2001-\mathrm{Q} 3$ & 4191 & 435 & $10.4 \%$ & 2177.2 & 155.5 & $7.1 \%$ \\
\hline $2001-\mathrm{Q} 4$ & 4084 & 408 & $10.0 \%$ & 2855.8 & 163.8 & $5.7 \%$ \\
\hline $2002-\mathrm{Q} 1$ & 3979 & 391 & $9.8 \%$ & 2710.9 & 133.0 & $4.9 \%$ \\
\hline $2002-\mathrm{Q} 2$ & 3865 & 376 & $9.7 \%$ & 2139.5 & 111.1 & $5.2 \%$ \\
\hline $2002-\mathrm{Q} 3$ & 3753 & 356 & $9.5 \%$ & 1702.5 & 79.1 & $4.6 \%$ \\
\hline $2002-\mathrm{Q} 4$ & 3655 & 344 & $9.4 \%$ & 1953.1 & 91.2 & $4.7 \%$ \\
\hline $2003-\mathrm{Q} 1$ & 3525 & 324 & $9.2 \%$ & 1951.6 & 76.2 & $3.9 \%$ \\
\hline 2003 - Q2 & 3432 & 307 & $8.9 \%$ & 2366.1 & 108.7 & $4.6 \%$ \\
\hline $2003-\mathrm{Q} 3$ & 3359 & 294 & $8.8 \%$ & 2628.3 & 126.5 & $4.8 \%$ \\
\hline $2003-\mathrm{Q} 4$ & 3323 & 278 & $8.4 \%$ & 2947.0 & 141.9 & $4.8 \%$ \\
\hline
\end{tabular}




\section{Table 6}

\section{Comparison of Financial Characteristics of Firms by Type Just Prior to the Time of Listing}

This table compares financial characteristics between market capitalization new listings and profitability new listings just prior to the time of listing. All of the data, with the exception of the market value of equity, is from the annual Compustat database preceding the listing date. The proportion negative net income(cash flow) is the percentage of all firms in that category that report negative net income (cash flow). The table presents median financial characteristics. Z-statistics ( $z$-stat) are for differences of medians tests. The level of significance is indicated by ${ }^{* * *}(1 \%),{ }^{* *}(5 \%),{ }^{*}(10 \%)$, using a two-tailed test.

\begin{tabular}{|c|c|c|c|c|c|c|}
\hline \multirow[t]{2}{*}{ Financial Characteristic } & \multicolumn{2}{|c|}{$\begin{array}{l}\text { Market } \\
\text { Capitalization } \\
\text { New Listing } \\
\text { (616 firms) }\end{array}$} & \multicolumn{2}{|c|}{$\begin{array}{l}\text { Profitability } \\
\text { New Listings } \\
\text { (221 firms) }\end{array}$} & \multirow[t]{2}{*}{ Difference } & \multirow[t]{2}{*}{ z-stat } \\
\hline & $\mathrm{N}$ & Median & $\mathrm{N}$ & Median & & \\
\hline Assets (\$ million) & 616 & 18.2 & 221 & 34.9 & -16.7 & $-7.55^{* * *}$ \\
\hline Revenues (\$ million) & 600 & 9.3 & 220 & 55.2 & -45.9 & $-15.38^{* * *}$ \\
\hline Book Value of Equity (\$ million) & 616 & -2.1 & 219 & 8.6 & -10.8 & $-10.91^{* * *}$ \\
\hline Market Value of Equity (\$ million) & 581 & 244.7 & 187 & 133.5 & 111.2 & $5.37^{* * *}$ \\
\hline Operating Income ( $\$$ million) & 595 & -5.9 & 220 & 8.4 & -14.3 & $-18.83^{* * *}$ \\
\hline Net Income (\$ million) & 599 & -8.2 & 220 & 3.9 & -12.1 & $-21.42^{* * *}$ \\
\hline Proportion Negative Net Income & 616 & $89.4 \%$ & 221 & $0.9 \%$ & $88.5 \%$ & $23.84^{* * *}$ \\
\hline Operating Income/Assets & 595 & $-38.6 \%$ & 220 & $21.5 \%$ & $-60.1 \%$ & $-20.43^{* * *}$ \\
\hline Net Income/ Assets & 599 & $-48.6 \%$ & 220 & $10.4 \%$ & $-59.0 \%$ & $-21.06^{* * *}$ \\
\hline Cash from Operations ( $\$$ million) & 600 & -4.6 & 220 & 4.0 & -8.5 & $-16.86^{* * *}$ \\
\hline Proportion Negative Cash Flow & 616 & $82.3 \%$ & 221 & $14.0 \%$ & $68.3 \%$ & $18.16^{* * *}$ \\
\hline Cash From Operations/Assets & 600 & $-27.2 \%$ & 220 & $11.6 \%$ & $-38.8 \%$ & $-17.71^{* * *}$ \\
\hline Asset Growth & 372 & $130.0 \%$ & 135 & $36.2 \%$ & $93.8 \%$ & $6.38^{* * *}$ \\
\hline Revenues Growth & 323 & $110.0 \%$ & 133 & $34.6 \%$ & $75.4 \%$ & $7.73^{* * *}$ \\
\hline
\end{tabular}




\section{Table 7}

\section{Comparison of Financial Characteristics for Market Capitalization New Listings and Profitability New Listings across Event Time}

This table presents financial characteristics of all trading securities by type over time. NI/Assets is net income before extraordinary items divided by total assets. OI/Assets is operating income divided by total assets. CFO/Assets is cash flows from operations divided by total assets. $R G R$ is the change in revenues divided by last year's revenues. The table presents the median performance in event time, where year 1 is the year that includes the listing date and years 2 through 4 are subsequent years. Zstatistics are for differences of medians tests. The level of significance is indicated by ${ }^{* * *}(1 \%),{ }^{* *}(5 \%),{ }^{*}(10 \%)$ using a two tailed test.

\begin{tabular}{|c|c|c|c|c|c|}
\hline Metric & $\begin{array}{l}\text { New Listing } \\
\text { Standard }\end{array}$ & Year 1 & Year 2 & Year 3 & Year 4 \\
\hline NI/Assets & $\begin{array}{l}\text { Mkt. Cap. } \\
\text { Profitability } \\
\text { Difference } \\
\text { z-statistic }\end{array}$ & $\begin{array}{c}-16.3 \% \\
5.8 \% \\
-22.1 \% \\
-17.96^{* * *}\end{array}$ & $\begin{array}{c}-24.3 \% \\
4.4 \% \\
-28.7 \% \\
-14.01^{* * *}\end{array}$ & $\begin{array}{c}-31.0 \% \\
2.4 \% \\
-33.4 \% \\
-12.77^{* * *}\end{array}$ & $\begin{array}{c}-19.6 \% \\
1.9 \% \\
-21.5 \% \\
-9.47^{* * *}\end{array}$ \\
\hline OI/Assets & $\begin{array}{l}\text { Profitability } \\
\text { Type } 1 \\
\text { Difference } \\
\text { z-statistic }\end{array}$ & $\begin{array}{c}-14.0 \% \\
15.2 \% \\
-29.1 \% \\
-17.94^{* * *}\end{array}$ & $\begin{array}{c}-14.2 \% \\
11.9 \% \\
-26.1 \% \\
-14.25^{* * *}\end{array}$ & $\begin{array}{c}-14.9 \% \\
10.5 \% \\
-25.3 \% \\
-12.91^{* * *}\end{array}$ & $\begin{array}{c}-7.1 \% \\
10.2 \% \\
-17.3 \% \\
-10.00^{* * *}\end{array}$ \\
\hline $\mathrm{CFO} /$ Assets & $\begin{array}{l}\text { Mkt. Cap. } \\
\text { Profitability } \\
\text { Difference } \\
\text { z-statistic }\end{array}$ & $\begin{array}{c}-8.9 \% \\
6.8 \% \\
-15.7 \% \\
-14.93^{* * *}\end{array}$ & $\begin{array}{c}-11.1 \% \\
6.6 \% \\
-17.7 \% \\
-13.01^{* * *}\end{array}$ & $\begin{array}{c}-10.6 \% \\
6.5 \% \\
-17.1 \% \\
-11.66^{* * *}\end{array}$ & $\begin{array}{c}-5.8 \% \\
6.6 \% \\
-12.4 \% \\
-9.25^{* * *}\end{array}$ \\
\hline RGR & $\begin{array}{l}\text { Mkt. Cap. } \\
\text { Profitability } \\
\text { Difference } \\
\text { z-statistic }\end{array}$ & $\begin{array}{c}157.3 \% \\
40.3 \% \\
117.1 \% \\
13.54^{* * * *}\end{array}$ & $\begin{array}{l}86.8 \% \\
27.2 \% \\
59.6 \% \\
8.31^{* * * *}\end{array}$ & $\begin{array}{c}7.7 \% \\
12.1 \% \\
-4.5 \% \\
-1.44\end{array}$ & $\begin{array}{c}3.2 \% \\
2.9 \% \\
0.3 \% \\
0.17\end{array}$ \\
\hline $\begin{array}{l}\text { Number of } \\
\text { Observations }\end{array}$ & $\begin{array}{l}\text { Mkt. Cap. } \\
\text { Profitability }\end{array}$ & $\begin{array}{l}599 \\
219\end{array}$ & $\begin{array}{l}523 \\
201\end{array}$ & $\begin{array}{l}442 \\
179\end{array}$ & $\begin{array}{l}380 \\
165\end{array}$ \\
\hline
\end{tabular}




\section{Table 8}

\section{Return Performance by Event Time}

This table presents stock returns for firms by type using CRSP data. Panel A presents the IPO underpricing premium on day 1. IPO Day 1 Returns are available for 174 of 221 profitability new listings and 537 of 616 market capitalization new listings. Panel $\mathrm{B}$ has cumulative buy and hold raw returns by quarter for three years following the new listing. Compounding starts from the first available data point on CRSP (excluding day 1 underpricing). When a firm delists, its delisting return is used. Panel $\mathrm{C}$ has cumulative buy and hold abnormal returns (BHARs). Market-adjusted returns are raw return minus CRSP value-weighted index. For size and B/M adjusted returns, the entire Nasdaq is divided each calendar year into market capitalization deciles, and each decile further divided into quintiles of book-to-market. Firms are matched to the corresponding portfolio each year for the calculation of the buy and hold returns for the control portfolio. T-statistics (tstat) and z-statistics are (z-stat) for differences of means and differences of proportions tests respectively, using pooled estimates of standard errors. The level of significance is indicated by ${ }^{* * *}(1 \%),{ }^{* *}(5 \%),{ }^{*}(10 \%)$ using a two tailed test.

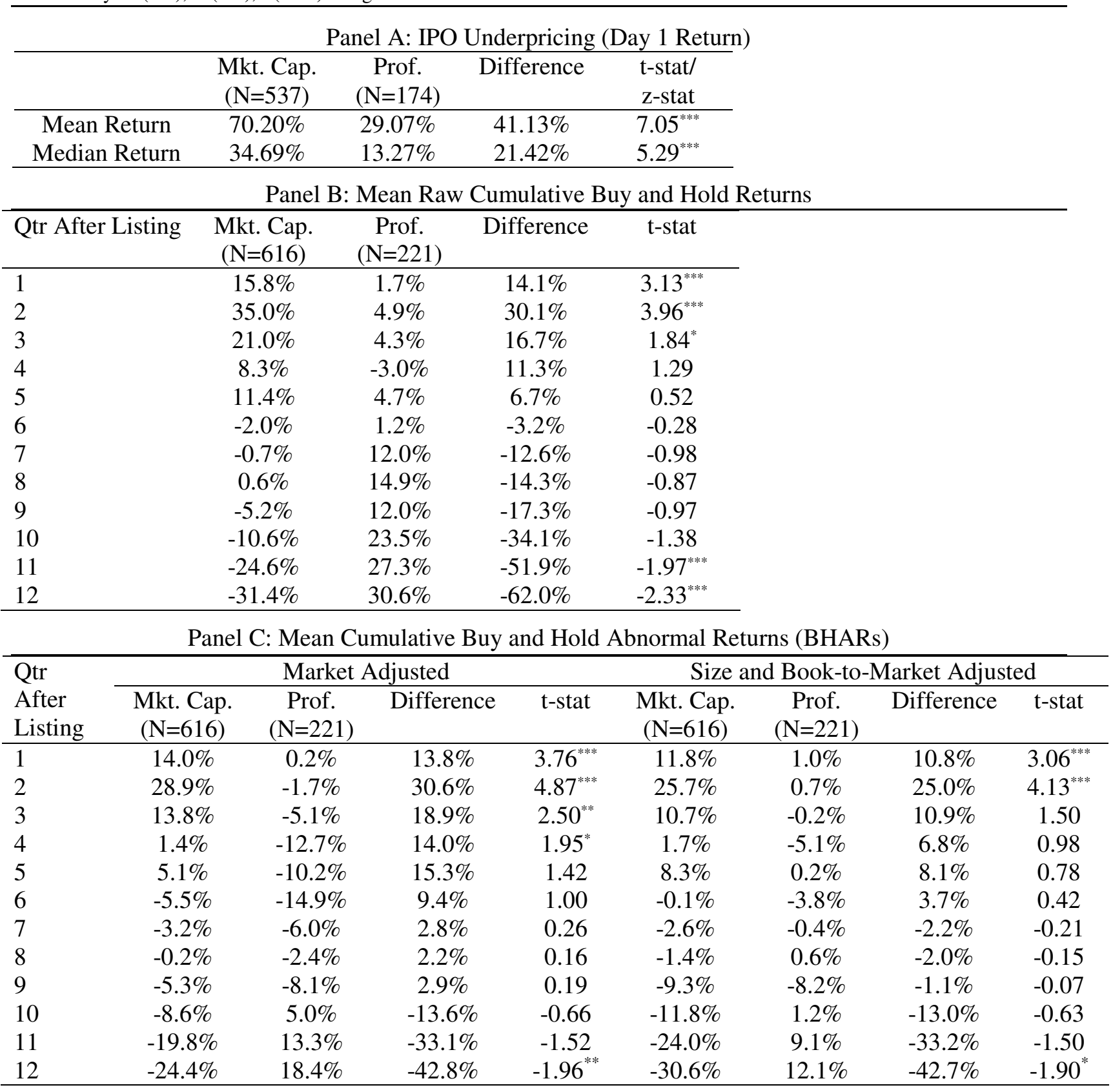




\section{Table 9}

\section{Regressions for Long Run Buy and Hold Returns}

The dependent variable is the raw buy-and-hold return for the first three years (CUMRET3) after listing excluding day 1 underpricing, adjusted for delisting return for all NNM new listings analyzed for which complete data was available. The independent variables are: PROFIT - a dummy that equals 1 for profitable firms and 0 for all other firms, NTA_JUMP - the proportion of net tangible assets that can be attributed to inclusion of IPO proceeds. (Pro-Forma Net Tangible Assets - Historical Net Tangible Assets)

$$
\text { Pro-Forma Net Tangible Assets }
$$

MSIZE - the log of market capitalization (based on lowest price for day 1 as available on CRSP), and either one of ASIZE: log of Total Assets or SSIZE: log of Sales from historical financials prior to listing date. Regressions are run only for firms with positive net tangible assets as it is used a scaling variable for NTA_JUMP. The level of significance is indicated by ${ }^{* * *}(1 \%),{ }^{* *}$ $(5 \%),{ }^{*}(10 \%)$ using a two tailed test.

Model 1: CUMRET3 $=\alpha_{0}+\beta_{1} *$ PROFIT $+\beta_{2} *$ NTA_JUMP $+\beta_{3} *$ IPORET $+\beta_{4} *$ MSIZE $+\beta_{5} *$ ASIZE $+\varepsilon$

Model 2: CUMRET3 $=\alpha_{0}+\beta_{1} *$ PROFIT $+\beta_{2} *$ NTA_JUMP $+\beta_{3} *$ IPORET $+\beta_{4} *$ MSIZE $+\beta_{5} *$ SSIZE $+\varepsilon$

\begin{tabular}{|c|c|c|}
\hline & Model 1 & Model 2 \\
\hline Intercept & $\begin{array}{l}0.605 \\
(0.73)\end{array}$ & $\begin{array}{l}0.360 \\
(0.46)\end{array}$ \\
\hline PROFIT & $\begin{array}{l}0.566 \\
(2.18)^{* *}\end{array}$ & $\begin{array}{l}0.634 \\
(2.18)^{* *}\end{array}$ \\
\hline NTA_JUMP & $\begin{array}{l}-1.533 \\
(-2.34)^{* *}\end{array}$ & $\begin{array}{l}-1.280 \\
(-2.19)^{* * *}\end{array}$ \\
\hline IPORET & $\begin{array}{l}-0.292 \\
(-2.22)^{* *}\end{array}$ & $\begin{array}{l}-0.279 \\
(-2.14)^{* *}\end{array}$ \\
\hline MSIZE & $\begin{array}{l}0.186 \\
(1.79)^{*}\end{array}$ & $\begin{array}{l}0.151 \\
(1.56)\end{array}$ \\
\hline ASIZE & $\begin{array}{l}-0.125 \\
(-1.12)\end{array}$ & \\
\hline SSIZE & & $\begin{array}{l}-0.070 \\
(-0.78)\end{array}$ \\
\hline Adjusted $\mathrm{R}^{2}$ & $2.18 \%$ & $2.08 \%$ \\
\hline $\mathrm{N}$ & 695 & 695 \\
\hline
\end{tabular}




\section{Table 10}

\section{Delisting Frequency by Event Time}

This table presents delisting information for firms by type using CRSP data. Panel A presents all delistings, while Panel B focuses on delistings related to poor performance. A delisting is considered a poor performance related delisting if either the delisting code in CRSP was in the 400s (liquidations) or 500s (dropped by Nasdaq), or if the delisting code was 231,233 or 235 (merger related) and cumulative returns till delisting was negative. T-statistics (tstat) and z-statistics are (z-stat) for differences of means and differences of proportions tests respectively, using pooled estimates of standard errors. The level of significance is indicated by ${ }^{* * *}(1 \%),{ }^{* *}(5 \%),{ }^{*}(10 \%)$ using a two tailed test.

Panel A: All Delistings - Cumulative Delisting Frequencies by Group

\begin{tabular}{|c|c|c|c|c|c|c|}
\hline \multirow{2}{*}{$\begin{array}{l}\text { Qtr } \\
\text { After } \\
\text { Listing }\end{array}$} & \multicolumn{2}{|c|}{$\begin{array}{c}\text { Mkt. Cap. } \\
(\mathrm{N}=616)\end{array}$} & \multicolumn{2}{|c|}{$\begin{array}{c}\text { Prof. } \\
(\mathrm{N}=221)\end{array}$} & \multirow[t]{2}{*}{$\begin{array}{l}\text { Difference in } \\
(\%) \text { delisted }\end{array}$} & \multirow[t]{2}{*}{ z-stat } \\
\hline & $\mathrm{N}$ & $(\%)$ & $\mathrm{N}$ & $(\%)$ & & \\
\hline 1 & 1 & $(0.2 \%)$ & 0 & $(0.0 \%)$ & $0.2 \%$ & 0.57 \\
\hline 2 & 7 & $(1.1 \%)$ & 1 & $(0.5 \%)$ & $0.7 \%$ & 0.76 \\
\hline 3 & 22 & $(3.6 \%)$ & 4 & $(1.8 \%)$ & $1.8 \%$ & 1.28 \\
\hline 4 & 43 & $(7.0 \%)$ & 6 & $(2.7 \%)$ & $4.3 \%$ & $2.23^{* *}$ \\
\hline 5 & 68 & $(11.0 \%)$ & 8 & $(3.6 \%)$ & $7.4 \%$ & $3.12^{* * * *}$ \\
\hline 6 & 91 & $(14.8 \%)$ & 16 & $(7.2 \%)$ & $7.5 \%$ & $2.82^{* * *}$ \\
\hline 7 & 121 & $(19.6 \%)$ & 25 & $(11.3 \%)$ & $8.3 \%$ & $2.74^{* * * *}$ \\
\hline 8 & 150 & $(24.4 \%)$ & 29 & $(13.1 \%)$ & $11.2 \%$ & $3.45^{* * *}$ \\
\hline 9 & 173 & $(28.1 \%)$ & 33 & $(14.9 \%)$ & $13.2 \%$ & $3.84^{* * * *}$ \\
\hline 10 & 194 & $(31.5 \%)$ & 37 & $(16.7 \%)$ & $14.8 \%$ & $4.15^{* * *}$ \\
\hline 11 & 213 & $(34.6 \%)$ & 44 & $(19.9 \%)$ & $14.7 \%$ & $4.02^{* * *}$ \\
\hline 12 & 259 & $(42.0 \%)$ & 54 & $(24.4 \%)$ & $17.6 \%$ & $4.60^{* * *}$ \\
\hline $\begin{array}{l}\text { NOT DELISTED } \\
\text { (after } 12 \text { qtrs) }\end{array}$ & 357 & $(58.0 \%)$ & 167 & $(75.6 \%)$ & $-17.6 \%$ & $-4.60^{* * *}$ \\
\hline
\end{tabular}

Panel B: Poor Performance Related Delistings - Cumulative Delisting Frequencies by Group

\begin{tabular}{lcccccc}
\hline $\begin{array}{l}\text { Qtr } \\
\text { After } \\
\text { Listing }\end{array}$ & $\begin{array}{c}\text { Mkt. Cap. } \\
(\mathrm{N}=616)\end{array}$ & $\begin{array}{c}\text { Prof. } \\
(\mathrm{N}=221)\end{array}$ & $\begin{array}{c}\text { Difference in } \\
(\%) \text { delisted }\end{array}$ & Z-stat \\
\hline & $\mathrm{N}$ & $(\%)$ & $\mathrm{N}$ & $(\%)$ & & \\
\hline 1 & 0 & $(0.0 \%)$ & 0 & $(0.0 \%)$ & $0.0 \%$ & 0.00 \\
2 & 3 & $(0.5 \%)$ & 0 & $(0.0 \%)$ & $0.5 \%$ & 0.89 \\
3 & 7 & $(1.1 \%)$ & 0 & $(0.0 \%)$ & $1.1 \%$ & 1.37 \\
4 & 21 & $(3.4 \%)$ & 2 & $(0.9 \%)$ & $2.5 \%$ & $1.82^{* * *}$ \\
5 & 43 & $(7.0 \%)$ & 3 & $(1.4 \%)$ & $5.6 \%$ & $2.89^{* * *}$ \\
6 & 64 & $(10.4 \%)$ & 9 & $(4.1 \%)$ & $6.3 \%$ & $2.73^{* * *}$ \\
7 & 91 & $(14.8 \%)$ & 14 & $(6.3 \%)$ & $8.4 \%$ & $3.13^{* * *}$ \\
8 & 119 & $(19.3 \%)$ & 16 & $(7.2 \%)$ & $12.1 \%$ & $4.02^{* * *}$ \\
9 & 139 & $(22.6 \%)$ & 18 & $(8.1 \%)$ & $14.4 \%$ & $4.52^{* * *}$ \\
10 & 154 & $(25.0 \%)$ & 21 & $(9.5 \%)$ & $15.5 \%$ & $4.69^{* * *}$ \\
11 & 173 & $(28.1 \%)$ & 28 & $(12.7 \%)$ & $15.4 \%$ & $4.49^{* * *}$ \\
12 & 218 & $(35.4 \%)$ & 38 & $(17.2 \%)$ & $18.2 \%$ & $4.95^{* * *}$ \\
\hline
\end{tabular}




\section{Table 11}

\section{Stock Return Volatilities for Market Capitalization and Profitability NNM New Listings}

This table presents stock return volatilities for all NNM new listings, market capitalization new listings, profitability new listings, and for the Nasdaq index. Panel A compares firm level volatilities for all NNM new listings with the Nasdaq index from 1998 through 2004. Panel B compares firm level volatilities for all listings up till that point for market capitalization new listings with profitability new listings from 1998 through 2004. Panel C compares firm level volatilities for market capitalization new listings with profitability new listings in event time. Firm level volatility, $\sigma_{\text {Reti }}$ is the standard deviation of all available returns for a given firm i in a given annual period. A firm needs to have at least 50 valid return observations for volatility to be computed. $\sigma_{\text {Ret }}$ is the mean firm level volatility across all firms. Volatilities are annualized by multiplying by $\sqrt{252}$. Level of significance is denoted by ${ }^{* * *}(1 \%),{ }^{* *}$ $(5 \%),{ }^{*}(10 \%)$, using a two-tailed difference of means test using pooled standard errors.

\begin{tabular}{|c|c|c|c|c|c|c|}
\hline \multicolumn{7}{|c|}{$\begin{array}{l}\text { Panel A: Comparisons of Mean Firm Level Return Volatilities of All NNM New Listings } \\
\text { with the Nasdaq Index }\end{array}$} \\
\hline \multirow[t]{2}{*}{ Year } & \multicolumn{2}{|c|}{ NNM New Listings } & \multicolumn{2}{|c|}{ Nasdaq Index } & \multirow[t]{2}{*}{ difference } & \multirow[t]{2}{*}{ t-stat } \\
\hline & $\mathrm{N}$ & $\sigma_{\text {Ret }}$ & $\mathrm{N}$ & $\sigma_{\text {Ret }}$ & & \\
\hline 1998 & 277 & $88.7 \%$ & 5672 & $97.3 \%$ & $-8.6 \%$ & $-6.65^{* * *}$ \\
\hline 1999 & 558 & $102.6 \%$ & 5480 & $97.3 \%$ & $5.4 \%$ & $4.09^{* * *}$ \\
\hline 2000 & 747 & $124.9 \%$ & 5288 & $107.0 \%$ & $17.9 \%$ & $12.14^{* * *}$ \\
\hline 2001 & 660 & $123.4 \%$ & 4754 & $104.1 \%$ & $19.3 \%$ & $12.80^{* * *}$ \\
\hline 2002 & 525 & $107.3 \%$ & 4159 & $88.1 \%$ & $19.2 \%$ & $14.04^{* * *}$ \\
\hline 2003 & 445 & $74.2 \%$ & 3777 & $69.1 \%$ & $5.2 \%$ & $4.59^{* * *}$ \\
\hline 2004 & 381 & $57.8 \%$ & 3554 & $54.3 \%$ & $3.5 \%$ & $3.85^{* * *}$ \\
\hline \multirow{3}{*}{ Panel t } & 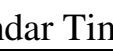 & 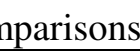 & 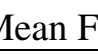 & vel $R_{f}$ & tilities & ype \\
\hline & \multicolumn{2}{|c|}{ Market Capitalization } & \multicolumn{2}{|c|}{ Profitability } & difference & t-stat \\
\hline & $\mathrm{N}$ & $\sigma_{\text {Ret }}$ & $\mathrm{N}$ & $\sigma_{\text {Ret }}$ & & \\
\hline 1998 & 148 & $97.7 \%$ & 129 & $78.5 \%$ & $19.2 \%$ & $5.56^{* * *}$ \\
\hline 1999 & 381 & $111.4 \%$ & 177 & $83.7 \%$ & $27.7 \%$ & $9.08^{* * * *}$ \\
\hline 2000 & 551 & $133.9 \%$ & 196 & $99.6 \%$ & $34.3 \%$ & $11.28^{* * *}$ \\
\hline 2001 & 478 & $133.5 \%$ & 182 & $96.8 \%$ & $36.8 \%$ & $7.91^{* * * *}$ \\
\hline 2002 & 367 & $116.2 \%$ & 158 & $86.7 \%$ & $29.5 \%$ & $3.58^{* * *}$ \\
\hline 2003 & 302 & $81.4 \%$ & 143 & $59.1 \%$ & $22.4 \%$ & $6.02^{* * *}$ \\
\hline 2004 & 248 & $60.5 \%$ & 133 & $52.8 \%$ & $7.8 \%$ & $2.71^{* * *}$ \\
\hline
\end{tabular}

Panel C: Event Time Comparisons of Mean Firm Level Return Volatilities by Listing Type

\begin{tabular}{ccccccc}
\hline Year After IPO & \multicolumn{2}{l}{ Market Capitalization } & \multicolumn{2}{c}{ Profitability } & difference & t-stat \\
& \multicolumn{7}{c}{$\sigma_{\text {Ret }}$} & $\mathrm{N}$ & $\sigma_{\text {Ret }}$ \\
1 & $\mathrm{~N}$ & $120.8 \%$ & 218 & $84.3 \%$ & $36.5 \%$ & $15.41^{* * * *}$ \\
2 & 585 & $129.3 \%$ & 212 & $90.5 \%$ & $38.9 \%$ & $10.88^{* * * *}$ \\
3 & 550 & $117.7 \%$ & 190 & $92.7 \%$ & $24.9 \%$ & $6.05^{* * * *}$ \\
4 & 447 & $106.6 \%$ & 170 & $83.4 \%$ & $23.2 \%$ & $3.52^{* * *}$ \\
5 & 361 & $77.5 \%$ & 150 & $73.0 \%$ & $4.4 \%$ & 0.64 \\
\hline
\end{tabular}

